Review

\title{
Bee Bread as a Promising Source of Bioactive Molecules and Functional Properties: An Up-To-Date Review
}

\author{
Meryem Bakour ${ }^{1}$, Hassan Laaroussi ${ }^{1}$, Driss Ousaaid ${ }^{1}{ }^{\mathbb{D}}$, Asmae El Ghouizi $^{1}$, Imane Es-Safi ${ }^{2} \mathbb{D}$, \\ Hamza Mechchate ${ }^{2, *}$ (D) and Badiaa Lyoussi ${ }^{1}$
}

1 Laboratory of Natural Substances, Pharmacology, Environment, Modeling, Health and Quality of Life (SNAMOPEQ), Faculty of Sciences Dhar El Mahraz, University Sidi Mohamed Ben Abdallah, Fez 30000, Morocco; meryem.bakour@usmba.ac.ma (M.B.); hassan.laaroussi@usmba.ac.ma (H.L.); driss.ousaaid@usmba.ac.ma (D.O.); asmae.elghouizi@usmba.ac.ma (A.E.G.); lyoussi@gmail.com (B.L.)

2 Laboratory of Inorganic Chemistry, Department of Chemistry, University of Helsinki, 00014 Helsinki, Finland; Imane.essafi1@usmba.ac.ma

* Correspondence: Hamza.mechchate@helsinki.fi

Citation: Bakour, M.; Laaroussi, H.; Ousaaid, D.; El Ghouizi, A.; Es-Safi, I.; Mechchate, H.; Lyoussi, B. Bee Bread as a Promising Source of Bioactive Molecules and Functional Properties: An Up-To-Date Review. Antibiotics 2022, 11, 203. https://doi.org/ 10.3390 /antibiotics11020203

Academic Editor: Piotr Szweda

Received: 12 January 2022

Accepted: 31 January 2022

Published: 5 February 2022

Publisher's Note: MDPI stays neutral with regard to jurisdictional claims in published maps and institutional affiliations.

Copyright: (C) 2022 by the authors. Licensee MDPI, Basel, Switzerland. This article is an open access article distributed under the terms and conditions of the Creative Commons Attribution (CC BY) license (https:// creativecommons.org/licenses/by/ $4.0 /)$.

\begin{abstract}
Bee bread is a natural product obtained from the fermentation of bee pollen mixed with bee saliva and flower nectar inside the honeycomb cells of a hive. Bee bread is considered a functional product, having several nutritional virtues and various bioactive molecules with curative or preventive effects. This paper aims to review current knowledge regarding the chemical composition and medicinal properties of bee bread, evaluated in vitro and in vivo, and to highlight the benefits of the diet supplementation of bee bread for human health. Bee bread extracts (distilled water, ethanol, methanol, diethyl ether, and ethyl acetate) have been proven to have antioxidant, antifungal, antibacterial, and antitumoral activities, and they can also inhibit $\alpha$-amylase and angiotensin I-converting enzyme in vitro. More than 300 compounds have been identified in bee bread from different countries around the world, such as free amino acids, sugars, fatty acids, minerals, organic acids, polyphenols, and vitamins. In vivo studies have revealed the efficiency of bee bread in relieving several pathological cases, such as hyperglycemia, hyperlipidemia, inflammation, and oxidative stress.
\end{abstract}

Keywords: bee bread; bioactive molecules; health benefits; natural antioxidant; natural antibiotics

\section{Introduction}

Bee products are natural products that are either secreted by the body of bees through glands, i.e., venom, wax, and royal jelly, or collected and processed by the bees, i.e., nectar, pollen from flowers, and resin [1]. In recent years, research trends for bioactive molecules of natural origin have led to a proliferation of studies on bee products, including honey, propolis, royal jelly, bee bread, and bee pollen [2]. Bee bread is a unique bee product that is poorly known because, until a few years ago, beekeepers did not know the appropriate method for collecting this product without partially destroying the hive [3].

For honey bees, the nutrients necessary for the survival and maintenance of the health of colony populations come from two main sources, namely nectar/honeydew and pollen from flowers. Nectar and honeydew provide carbohydrates and pollen provides other dietary needs, such as lipids, proteins, vitamins, and minerals [4]. However, bees do not directly consume nectar/honeydew or pollen; in both cases, they induce biochemical changes, such that the nectar/honeydew turns into honey and the pollen turns into bee bread [5]. The process of making bee bread begins with the collection of pollen from flowers, which is then mixed by bees with the nectar or honey and saliva containing digestive enzymes [6]. At this stage, the pollen from flowers is transformed into bee pollen, stored in the pollen basket in the bee's hind legs, and carried to the hive, where the non-flying bees fill the cells of the hive with a mixture of bee pollen and honey. Then, a thin layer of wax is added to protect the mixture from oxygen. An anaerobic lactic fermentation process takes 
place, and the bee bread is produced (Figure 1). This type of lactic fermentation makes the bee bread more digestible and enriched with new nutrients [7]. Studies on the chemical composition of bee bread have shown that it is generally made up of water, protein, free amino acids, carbohydrates, fatty acids, and other bioactive molecules. This composition varies from one region to another depending on the honey plants' climatic conditions and seasonal variations. All these conditions make bee bread a potential functional food with distinct bioactive molecules [8,9].

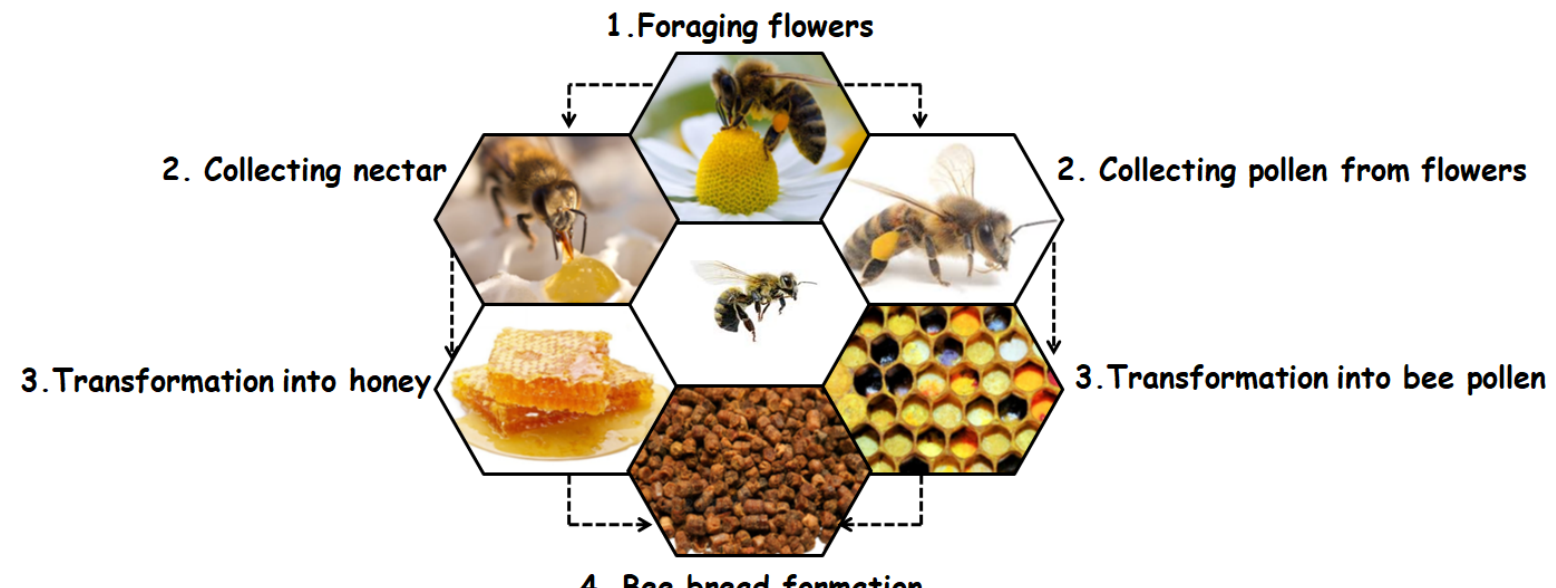

Figure 1. The process of forming bee bread in the hive.

In the life of bees, there are times when they are highly active, such as when colonies are reproducing or during periods of high wax production. At these times, the demand for pollen rises, and a decrease in pollen inflow (fall and early spring) or the existence of pollen of poor nutritional quality will have serious consequences for the colony. This directs bees to rely on their bee bread store for their needs [10]. In this review, we will underline the importance of bee bread, not only for bee food and the good health of the hive, but also its nutritional importance for humans and its richness in bioactive molecules with protective or curative effects.

\section{Methodology}

A comprehensive literature search was performed from October 2021 to January 2022. The search engines "Google-Scholar, Web of Science, Scopus, Science-Direct and Pub-Med" were used to collect information on bee bread, its chemical composition, and its biological activities in vitro and in vivo using keywords such as "composition of bee bread", "bee bread and patients", the antimicrobial effect of bee bread", "antiviral effect of bee bread", "bee bread and rats", and"effects of bee bread". The papers were collected, examined for relevance, and then their general ideas were summarized.

\section{Bee Bread Composition}

\subsection{Free Amino Acids}

Several studies have investigated the free amino acids content of bee bread. For instance, Malaysian bee bread was analyzed in two studies published by Mohammad et al. [11] and by Othman et al. [12]. In the first study, four multifloral bee breads were analyzed using chromatographic separation; the botanical origins of the samples were Mimosa pudica, Sphagneticola trilobata, Bidens pilosa, Cassia sp, Areca catechu, Peltophorum pterocarpum, Phaleria capitata, Cassia siamea, Citrus aurantifolia, and Ageratum conyzoides. In the second study, three samples were analyzed using the WatersAccQ Tag method. The results of the two studies revealed the presence of the following amino acids in bee bread samples: phenylalanine, valine, histidine, methionine, isoleucine, leucine, threonine, alanine, arginine, tyrosine, glycine, proline, hydroxyproline, serine, glutamic acid, aspartic 
acid, and lysine. Moreover, Donkersley et al. [13] studied fifty-one samples of bee bread from England, whose botanical origins were Trifolium, Impatiens, Rubus, Acer, Cirsium, Euscaphis, Cryptotaenia, Glycine, Coriandrum, Rosa, Prunus, Taraxacum, Camelina, Ranunculus, Salix, and Andira. The ultra-high-performance liquid chromatography (UHPLC) analysis of these samples showed the presence of aspartate, glutamate, asparagine, serine, glutamine, histidine, glycine, threonine, arginine, alanine, $\gamma$-aminobutyric acid, tyrosine, cysteine, valine, methionine, tryptophan, phenylalanine, isoleucine, leucine, lysine, and proline. The gas chromatography-mass spectrometry (GC-MS) analysis of two American samples studied by DeGrandi-Hoffman et al. [14] showed the presence of the following amino acids: alanine, aspartic acid, glutamine, serine, leucine, isoleucine, methionine, threonine, valine, tryptophan, cysteine, phenylalanine, and proline. In addition, Bayram et al. [15] analyzed five Turkish bee bread samples, and they found the following amino acids: tryptophan, taurine, 1-tyrosine, 1-phenylalanine, 1-isoleucine, 1-leucine, gamma-aminobutyric acid, 3-amino isobutyric acid, 1-methionine, 1-2-aminoadipic acid, beta-alanine, 1-aspartic acid, 1-glutamic acid, l-valine, 1-2-aminobutyric acid, ethanolamine, 1-alanine, 1-threonine, 1-serine, l-glycine, 1-asparagine, l-glutamine, 1-proline, sarcosine, 1-arginine, 1-cystathionine, 1-cystine, histidine, 1-ornithine, l-carnosine,1- lysine, and l-anserine(Table 1).

The origin of the amino acids in bee bread is generally attributed to both floral (nectar, honeydew, and main pollen) and animal (bee secretions) origins. Since the main source is pollen, the amino acid profile or certain characteristics of the amino acids could be important for the botanical classification of some bee products, such as bee pollen, honey, and bee bread. For instance, tryptophan is considered a promising biomarker of acaciarelated bee products, and arginine is a marker for chestnut-based hive products [16]. In addition to their role in the authentication of bee products, the amino acids contained in bee bread have been previously documented to have vital physiological roles in the human body. Accordingly, methionine, an essential amino acid, presents highly in functional foods, including bee products, participates in the DNA methylation reaction and protein synthesis, acts as glutathione (GSH) precursor, and acts as a powerful antioxidant agent by eliminating excess reactive oxygen species (ROS) and thus protects tissues from oxidative stress [17]. Arginine, an indispensable gluconeogenic amino acid, possesses immunomodulatory actions, including enhancing $\mathrm{T}$ cell $\left(\mathrm{CD} 8^{+}\right)$and macrophage functions [18]. Therefore, the incorporation of bee bread into the daily human diet as a valuable nutraceutical food complement is needed.

\subsection{Sugars}

Bees use sugars to produce the energy necessary for their survival. Several studies have been carried out on the sugar content of bee bread. For instance, bee workers need about $4 \mathrm{mg}$ /day of sugars to cover their daily energy [3,19]. The free sugar contents in bee bread were determined using high-performance liquid chromatography-refractive index detection (HPLC-RID) in a Moroccan multifloral sample (Bupleurum spinosum, Anethum graveolens, Calendula officinalis, Anacyclus, Quercus ilex, Eucalyptus, Punica granatum, and Acacia). The results showed that fructose was the major representative sugar with a concentration of $11.8 \pm 0.6 \mathrm{~g} / 100 \mathrm{~g}$, followed by glucose $(5.7 \pm 0.4 \mathrm{~g} / 100 \mathrm{~g})$, and a small amount of trehalose (0.92 $\pm 0.01 \mathrm{~g} / 100 \mathrm{~g}$ [20]). Similarly, Dranca et al. [21] documented that Romanian bee bread contains $19.73 \mathrm{~g} / 100 \mathrm{~g}$ of fructose and $8.82 \mathrm{~g} / 100 \mathrm{~g}$ of glucose, and a low percentage of melezitose and raffinose $(0.97 \mathrm{~g} / 100 \mathrm{~g}$ and $0.96 \mathrm{~g} / 100 \mathrm{~g}$, respectively). Moreover, the findings of Urcan et al. [22] for five multifloral bee bread samples (Brassicaceae, Poaceae, Myrtaceae, Rutaceae, Asteraceae, Fabaceae, Tiliaceae, Fabaceae, Rosaceae, Plantaginaceae, Fabaceae, Asteraceae, Lamiaceae, Salicaceae, Rosaceae, and Fagaceae) from Romania and India revealed by high-performance liquid chromatography diode array detection (HPLC-DAD) analysis showed that fructose was the major individual sugar, with values ranging from $13.97 \pm 0.05 \mathrm{~g} / 100 \mathrm{~g}$ to $19.58 \pm 0.03 \mathrm{~g} / 100 \mathrm{~g}$, followed by glucose $(6.40 \pm 0.010 \mathrm{~g} / 100 \mathrm{~g}$ to $15.13 \pm 0.02 \mathrm{~g} / 100 \mathrm{~g})$, and smaller quantities of mal- 
tose and turanose $(0.82 \pm 0.02 \mathrm{~g} / 100 \mathrm{~g}$ to $1.00 \pm 0.01 \mathrm{~g} / 100 \mathrm{~g}$ and $0.56 \pm 0.02 \mathrm{~g} / 100 \mathrm{~g}$ to $0.87 \pm 0.01 \mathrm{~g} / 100 \mathrm{~g}$, respectively).

On the contrary, in a study published by Mohammad et al. [11], a sugar profile revealed that glucose was the major free sugar contained in four Malaysian multifloral bee breads analyzed by HPLC coupled with an evaporative light scattering detector (ELSD); the values ranged between $10.270 \pm 0.140 \mathrm{~g} / 100 \mathrm{~g}$ and $12.397 \pm 0.980 \mathrm{~g} / 100 \mathrm{~g}$. The second highest sugar content was sucrose, ranging from $0.595 \pm 0.000 \mathrm{~g} / 100 \mathrm{~g}$ to $2.094 \pm 0.141 \mathrm{~g} / 100 \mathrm{~g}$; then fructose, ranging from $0.396 \pm 0.000$ to $1.488 \pm 0.140 \mathrm{~g} / 100 \mathrm{~g}$; and maltose, ranging from $0.694 \pm 0.140$ to $1.994 \pm 0.000 \mathrm{~g} / 100 \mathrm{~g}$ ) (Table 1 ). This high variability could be explained by numerous factors, such as the harvesting time, the botanical origin, and the decomposition of sugars by lactic acid bacteria [23].

\subsection{Fatty Acids}

Fatty acids are among the most important compounds in bee bread. Bakour et al. [20] analyzed Moroccan bee bread using gas chromatography coupled with flame ionization detection (GC-FID), and they identified and quantified fourteen saturated and eleven unsaturated fatty acids, in which the highest levels were represented by $\alpha$-linolenic and arachidonic acid, $25 \pm 1 \%$ and $23.2 \pm 0.5 \%$, respectively. On the other hand, Turkish bee bread was analyzed by Kaplan et al. [24,25] in two studies using GC-MS analysis and GC-FID analysis, and the results indicated that seventeen saturated fatty acids and twenty unsaturated fatty acids were detected in eight monofloral samples in the first study, and five monofloral samples in the second study. In a recent study published by Drancaet al. [21], the GC-MS analysis of Romanian bee bread showed a content of thirty-seven fatty acids, with a percentage of $23.13 \%$ for saturated fatty acids and $76.87 \%$ unsaturated fatty acids (Table 1). Keeping in view the previous investigations, it is well recognized that individual fatty acids are the same in different bee breads; however, their concentrations vary depending on the geo-climatic conditions, the floral origin of pollen flowers, or even within the same species of the same growth site [26,27].

It has been documented that fatty acids play a crucial role in the nutrition, reproduction, and development of bees [28]. Owing to their antibiotic functions, such as antibacterial activity and antifungal activity, fatty acids, especially lauric, myristic, linoleic, and linolenic acids, contribute greatly to bee colony hygiene [29].

\subsection{Minerals}

The minerals from soil are carried into plants by their roots, and into bee bread through the pollen of flowers, nectar, or honeydew. Bee bread is one of the richest hive products in terms of macro and microelements. Moroccan bee bread was analyzed by Bakour et al. [20],who showed that potassium $(338 \pm 8 \mathrm{mg} / 100 \mathrm{~g})$ was the predominant mineral followed by phosphorus ( $251 \pm 4 \mathrm{mg} / 100 \mathrm{~g})$, calcium (198 $\pm 4 \mathrm{mg} / 100 \mathrm{~g})$, magnesium $(61 \pm 2 \mathrm{mg} / 100 \mathrm{~g})$, iron $(27.3 \pm 0.3 \mathrm{mg} / 100 \mathrm{~g})$, sodium $(14.2 \pm 0.1 \mathrm{mg} / 100 \mathrm{~g})$, zinc $(3.31 \pm 0.04 \mathrm{mg} / 100 \mathrm{~g})$, and manganese $(2.6 \pm 0.1 \mathrm{mg} / 100 \mathrm{~g})$. The mineral content of bee bread may vary depending upon the agro-climatic conditions, specific melliferous plants, growth site, and harvesting season. Moreover, the methods used for sample collection and conditioning storage could affect the concentration and the mineral composition of bee bread [11].

In Malaysian bee bread, the most abundant mineral was potassium $(6524.9 \pm 610.6 \mathrm{mg} / \mathrm{kg})$, followed by phosphorus $(6402.28 \pm 163.29 \mathrm{mg} / \mathrm{kg})$, and magnesium $(1635.4 \pm 215.4 \mathrm{mg} / \mathrm{kg})$ [11]. Similarly, Eleazu et al. [30] reported that calcium, phosphorus, potassium, magnesium, iron, zinc, and manganese were detected at high concentrations in Malaysian bee bread. In addition, the ICP-MS analysis of Serbian bee bread samples showed their richness in sodium, magnesium, potassium, calcium, manganese, selenium, zinc, and copper. The most abundant minerals were potassium, calcium, and magnesium [31] (Table 1). 
Mineral elements are involved in the functioning of many biochemical and physiological processes in humans. For instance, a diet rich in potassium, an oligoelement that presents highly in bee bread samples of different floral and geographical origins, improves blood pressure and prevents cardiovascular diseases in both human and animal models [32,33]. Phosphorus, the sixth most abundant metal in the human body, is closely related to nucleic acid synthesis, enzyme activity, skeletal and non-skeletal muscle function, bone mineralization, energy, and lipid metabolism [34].

Micro-elements, including antioxidant minerals, such as zinc, iron, manganese, selenium, and copper, act as cofactors of many antioxidant and non-antioxidant enzymes. Therefore, they are effective components of metabolism and human body integrity [35].

\subsection{Organic Acids}

Organic acids are responsible for the microbial and digestive properties of bee products, and they are also used as food preservatives [36]. The information available in the literature on the organic acid content of bee bread remains limited. In a recent study conducted by Dranca et al. [21], the HPLC-DAD analysis of Romanian bee bread revealed the presence of the following organic acids: gluconic acid $(79.2 \mathrm{~g} / \mathrm{kg})$, formic acid $(6.75 \mathrm{~g} / \mathrm{kg})$, acetic acid $(10.7 \mathrm{~g} / \mathrm{kg})$, propionic acid $(1.3 \mathrm{~g} / \mathrm{kg})$, and butyric acid $(0.33 \mathrm{~g} / \mathrm{kg})$. While in the Moroccan bee bread studied by Bakour et al. [20], the only organic acid found was oxalic acid. Organic acid content in bee bread varies depending upon the botanical origin (age, species, and vegetable tissue) (Table 1). Since bee bread is a bee pollen-derived product, its organic acid content can be compared to that of bee pollen. Kalaycioglu and coworkers [36] analyzed six multifloral and four monofloral bee pollen samples collected from different regions of Turkey and reported that gluconic acid (5.9-32 g/ kg), lactic acid $(0.72-1.2 \mathrm{~g} / \mathrm{kg})$, tartaric acid $(0.17-0.30 \mathrm{~g} / \mathrm{kg})$, succinic acid $(0.092-0.40 \mathrm{~g} / \mathrm{kg})$, and citric acid $(0.19-0.31 \mathrm{~g} / \mathrm{kg})$ were the most quantified organic acids. Gluconic acid, a main organic acid in bee bread, exhibited potent antibacterial activities against anaerobic (Porphyromonasgingivalis), Gram-negative (Escherichia coli), and Gram-positive bacteria (Staphylococcus aureus), as well as achieved effective biofilm penetration. Importantly, polymyxin B associated with gluconic acid exhibited good biofilm penetration and high antibacterial action [37]. In addition, acetic acid, another valuable component found in bee products, has been documented to have anti-fungal effects against toxigenic Aspergillus flavus [38]. Therefore, bee bread extracts could be used as promising antibiotic and natural food preservative agents.

\subsection{Vitamins}

Vitamins are organic compounds tha thave several biochemical roles in growth, the regulation of mineral metabolism, and cell differentiation; some also possess antioxidant activity and others play the role of precursors of enzyme cofactors [39]. According to the literature, vitamin content is highly dependent on the plant origin of bee bread. Loper et al. [40] conducted a comparative study of the vitamin content in bee pollen and bee bread samples after seven, twenty-one, and forty-two days from the same plant source (Prunus dulcis), and they found that the vitamin content decreased by passing pollen from the flowers throughout the forty-two days of storage. Until present, few studies (Table 1) have been conducted on the vitamin composition of bee bread. Bakour and coworkers [20] reported that Moroccan bee bread contained $\alpha$-tocopherol and $\delta$-tocopherol with concentrations of $10.5 \pm 0.8$ and $0.4 \pm 0.04 \mathrm{mg} / 100 \mathrm{~g}$ of bee bread (BB), respectively. Vitamin quantification was also the subject of other investigations. In fact, Salma Malihah et al. and Chinedum et al. $[11,20,31]$ studied Malaysian bee bread and revealed the presence of vita$\min C(11.52 \mathrm{mg} / 100 \mathrm{~g}), \alpha$-tocopherol, $\delta$-tocopherol, vitamin A $(146.8 \mathrm{mg} / 100 \mathrm{~g})$, vitamin $\mathrm{E}(46.27 \mathrm{mg} / 100 \mathrm{~g})$, thiamine $(6.20 \mathrm{mg} / 100 \mathrm{~g})$, and riboflavin $(1.50 \mathrm{mg} / 100 \mathrm{~g})$ (Table 1).

Since there is no specification for the vitamin content in bee bread, a bee pollenderived product, the specifications for the vitamin composition of bee pollen suggest contents between 0.6 and $2 \mathrm{mg} / 100 \mathrm{~g}$ for riboflavin and between 0.6 and $1.3 \mathrm{mg} / 100 \mathrm{~g}$ for 
thiamine [41], thus allowing us to highlight bee bread as a dietary supplement and natural source of valuable vitamins.

\subsection{Polyphenolic Composition}

Owing to the development of advanced techniques for the separation and purification of molecules, such as gas chromatography (GC) and high-performance liquid chromatography (HPLC), as well as other identification techniques, such as mass spectroscopy (MS), thin-layer chromatography (TLC), and other combined techniques, several bioactive components have been identified in bee bread from different geographical origins (Table 1).

Polyphenol compounds are secondary metabolites produced by plants in response to different biotic and abiotic stress conditions [42]. These chemical compounds are divided into two groups: hydrophilic antioxidants, such as vitamin $C$ and phenolic acids, and lipophilic antioxidants, such as carotenoids, tocopherols, and flavonoids [43]. The high content of antioxidants in bee bread is responsible for its bioactivities. For instance, Oltica and coworkers [44] found that there was a good correlation between the content of antioxidants (polyphenols, flavonols, flavones, and flavanones) and the antioxidant activity of scavenging free radicals carried out by 2,2-diphenyl-1-picrylhydrazyl (DPPH), trolox equivalent antioxidant capacity (TEAC), and ferric reducing antioxidant power (FRAP) tests, which explains their contribution to the antioxidant effects of bee bread extracts. It is well known that the soil nature, geographical conditions, and plant species highly influence the phytochemical composition of functional foods, including bee product extracts [7]. Furthermore, the solvent and extraction method used influence the quantity and the selectivity of the extract components [45]. Chemical variability has been observed in the composition of bee bread extracts of different geographical and floral origins.

The phenolic screening of multifloral Moroccan bee bread by HPLC showed the presence of thirteen phenolic compounds, where isorhamnetin-O-hexosyl-O-rutinoside was the most representative [20]. Similarly, Sobral et al. [46] analyzed six bee bread samples harvested from different apiaries located in the north of Portugal. High-performance liquid chromatography-diode array detection coupled to tandem mass spectrometry (HPLCDAD-ESI/MS) analysis revealed the presence of thirty-two phenolic compounds, of which flavonol derivatives, mainly quercetin, kaempferol, myricetin, isorhamnetin, and herbacetin glycoside derivatives, were the main quantified antioxidant molecules.

A study conducted by Urcan et al. [22] revealed that five samples of bee bread from Romania and India contained kaempferol-3-O-glycoside, a hydroxycinnamic acid derivative, quercetin-3-O-sophoroside, a kaempferol-3-O-derivative, a hydroxycinnamic acid derivative, myrcetin, trycetin, luteolin, herbacetin-3-O-glycoside, quercetin-3-O-glycoside, and isoramnethin-3-O-glycoside. Similarly, Lithuanian, Romanian, Turkish, Portuguese, and Georgian bee bread samples showed the presence of several polyphenolic components belonging to different chemical groups, such as p-coumaric acid, kaempferol, chrysin, apigenin, caffeic acid, rosmarinic acid, myricetin, luteolin, naringin, rutin, and quercetin [15,21,47-49]. In addition, the GC-MS analysis of three bee bread samples from Poland showed the presence of kaempferol and apigenin [50] (Table 1).

Flavonoids, phenolic acids, and other antioxidant components are recognized as effective functional molecules, displaying numerous bio-pharmacological potentialities. In fact, several researchers suggest the use of bee bread as a common food preservative and bio-functional dietary supplement, or as a therapeutic strategy in the prevention of oxidative stress and associated ailments, such as cardio-metabolic, neurodegenerative, and cancerous diseases $[46,51,52]$.

\subsection{Microorganisms}

Bee bread is a complex product that contains different microorganisms, such as bacteria and fungi, involved in the production process of bee bread to enrich it with newly produced nutrients. The micro-organisms found in bee bread originate from the bee's saliva, added to pollen as a raw matter of bee bread. This microbiome plays an important role in the 
sustenance of larva and in adult bee's health, including in making carbohydrates digestible and providing different nutrients with added value. Furthermore, the richness of bee bread in microorganisms can give it the properties of a probiotic product [53]. A study conducted by Dimov et al. [54] showed the following fungi composition in bee bread: Cladosporium, Penicillium, Alternaria, Monilinia, Sclerotinia, Ascosphaera, Toxicocladosporium, Botrytis, Pseudopithomyces, Camerosporium, Paraconiothyrium, Podosphaera, Golovinomyces, Paraphaeosphaeria, Periconia, and Septoriella. In addition, it was found that bee bread was rich in lactic acid bacteria, such as Apilactobacilluskunkeei, Lactiplantibacillus plantarum, Fructobacillusfructosus, Levilactobacillus brevis, Lactobacillus delbrueckii, Lactobacillus musae, Lactobacillus crustorum, and Lactobacillus delbrueckii [54-56].

\subsection{Enzymes}

Bee bread contains high amounts of enzymes, of which amylase, invertase, phosphatases, transferases, and glucose oxidase are the most important. Invertase and glucose oxidase are mainly produced in the hypopharyngeal glands, and are added by the bees to complete the honey maturation process. However, some enzymes, such as catalase and phosphatase, originate from nectar, honeydew, or pollen [57]. Enzyme cofactors, such as biotin, glutathione, and NAD, have also been found in bee bread. These enzymes can transform high molecular weight compounds into other low molecular weight molecules, such as polysaccharides and proteins. This makes bee bread more digestible than bee pollen [58,59]. 
Table 1. The chemical composition of bee bread from different countries in the world.

\begin{tabular}{|c|c|c|c|c|c|}
\hline & Component & Method Used & Country & Botanical Origin & References \\
\hline \multirow{4}{*}{ Free amino acids } & $\begin{array}{l}\text { Tryptophan, Taurine, L-Tyrosine, L-Phenylalanine, L-isoleucine, } \\
\text { L-Leucine, Gamma-aminobutyric acid, 3-Amino isobutyric acid, } \\
\text { L-Methionine, L-2-Aminoadipic acid, Beta-Alanine, L-Aspartic acid, } \\
\text { L-Glutamic acid, L-Valine, L-2-aminobutyric acid, Ethanolamine, } \\
\text { L-Alanine, L-Threonine, L-Serine, L-Glycine, L-Asparagine, } \\
\text { L-Glutamine, L-Proline, Sarcosine, L-Arginine, L-Cystathionine, } \\
\text { L-Cystine, Histidine, L-ornithine, L-Carnosine, L-Lysine, and } \\
\text { L-Anserine }\end{array}$ & LC-MS/MS & Turkey & $\begin{array}{c}\text { Five samples } \\
\text { (not determined) }\end{array}$ & [15] \\
\hline & $\begin{array}{l}\text { Phenylalanine, Valine, Histidine, Methionine, Isoleucine, Leucine, } \\
\text { Threonine, Alanine, Arginine, Tyrosine, Glycine, Proline, } \\
\text { Hydroxyproline, Serine, Glutamic acid, Aspartic acid, andLysine }\end{array}$ & Chromatographic separation & Malaysia & $\begin{array}{c}\text { Four multifloral samples } \\
\text { (Mimosa pudica, Sphagneticolatrilobata, Bidens ilosa, } \\
\text { Cassia sp, Areca catechu, Peltophorumpterocarpum, } \\
\text { Phaleria capitata, Cassia siamea, Citrus aurantifolia, and } \\
\text { Ageratum conyzoides) }\end{array}$ & [11] \\
\hline & $\begin{array}{c}\text { Aspartate, Glutamate, Asparagine, Serine, Glutamine, Histidine, } \\
\text { Glycine, Threonine, Arginine, Alanine, } \gamma \text {-aminobutyric acid, Tyrosine, } \\
\text { Cysteine, Valine, Methionine, Tryptophan, Phenylalanine, Isoleucine, } \\
\text { Leucine, Lysine, and Proline }\end{array}$ & UHPLC & England & $\begin{array}{l}\text { Fifty-one samples of bee bread (Trifolium, Impatiens, } \\
\text { Rubus, Acer, Cirsium, Euscaphis, Cryptotaenia, Glycine, } \\
\text { Coriandrum, Rosa, Prunus, Taraxacum, Camelina, } \\
\text { Ranunculus, Salix, and Andira) }\end{array}$ & [13] \\
\hline & $\begin{array}{c}\text { Alanine, Aspartic acid, Glutamine, Serine, Leucine, Iso-leucine, } \\
\text { Methionine, Threonine, Valine, Tryptophan, Cysteine, Phenylalanine, } \\
\text { and Proline. }\end{array}$ & (GC/MS) & USA & $\begin{array}{c}\text { Two samples } \\
\text { (not determined) }\end{array}$ & [14] \\
\hline \multirow{3}{*}{ Sugars } & Trehalose, Glucose, and Fructose & HPLC-RID & Morocco & $\begin{array}{l}\text { One multifloral sample (Bupleurum spinosum, } \\
\text { Anethum graveolens, Calendula officinalis, Anacyclus, } \\
\text { Quercus ilex, Eucalyptus, Punica granatum, and Acacia) }\end{array}$ & [20] \\
\hline & Fructose, Glucose, Melezitose, andRaffinose & HPLC-RID & Romania & One sample (not determined). & [21] \\
\hline & Fructose, Glucose, Turanose, and Maltose & HPLC-DAD & $\begin{array}{l}\text { Romania and } \\
\text { India }\end{array}$ & $\begin{array}{l}\text { Five samples (Brassicaceae, Poaceae, Myrtaceae, } \\
\text { Rutaceae, Asteraceae, Fabaceae, Tiliaceae, Fabaceae, } \\
\text { Rosaceae, Plantaginaceae, Fabaceae, Asteraceae, } \\
\text { Lamiaceae, Salicaceae, Rosaceae, and Fagaceae) }\end{array}$ & [22] \\
\hline
\end{tabular}


Table 1. Cont.

\begin{tabular}{|c|c|c|c|c|c|}
\hline & Component & Method Used & Country & Botanical Origin & References \\
\hline & Fructose, Glucose, Sucrose, and Maltose & HPLC coupled with an ELSD & Malaysia & $\begin{array}{c}\text { Four multifloral samples (Mimosa pudica, } \\
\text { Sphagneticolatrilobata, Bidens ilosa, Cassia sp, Areca } \\
\text { catechu, Peltophorumpterocarpum, Phaleria capitata, } \\
\text { Cassia siamea, Citrus aurantifolia, and Ageratum } \\
\text { conyzoides) }\end{array}$ & [11] \\
\hline \multirow{3}{*}{ Microorganisms } & Lactobacillus kunkeei & RAPD-PCR & Turkey & Four samples (not identified). & [60] \\
\hline & $\begin{array}{c}\text { Cladosporium, Penicillium, Alternaria, Monilinia, Sclerotina, Ascosphaera, } \\
\text { Toxicocladosporium, Botrytis, Pseudopithomyces, Camerosporium, } \\
\text { Paraconiothyrium, Podosphaera, Golovinomyces, Paraphaeosphaeria, } \\
\text { Periconia, and Septoriella }\end{array}$ & NGS-sequencing & Bulgaria & Four samples (not identified). & [54] \\
\hline & $\begin{array}{c}\text { Apilactobacilluskunkeei, Lactiplantibacillus plantarum, } \\
\text { Fructobacillusfructosus, Levilactobacillus brevis, and Lactobacillus } \\
\text { delbrueckii }\end{array}$ & $\begin{array}{l}\text { PCR-DGGE analysis } \\
\text { RAPD-PCR analysis }\end{array}$ & Italy & Twelve samples (not identified) & [55] \\
\hline \multirow[t]{2}{*}{ Organic acids } & Oxalic acid & UFLC-PDA & Morocco & $\begin{array}{l}\text { One multifloral sample (Bupleurum spinosum, } \\
\text { Anethum graveolens, Calendula officinalis, Anacyclus, } \\
\text { Quercus ilex, Eucalyptus, Punica granatum, and Acacia) }\end{array}$ & [20] \\
\hline & $\begin{array}{l}\text { Gluconic acid, Formic acid, Lactic acid, Acetic acid, Succinic acid, } \\
\text { Propionic acid, Butyric acid }\end{array}$ & HPLC-DAD & Romania & One sample (not determined) & [21] \\
\hline \multirow[t]{3}{*}{ Vitamins } & Vitamin C & Method AOAC 967.21 & Malaysia & $\begin{array}{c}\text { Four multifloral samples (Mimosa pudica, } \\
\text { Sphagneticolatrilobata, Bidens pilosa } \\
\text {,Cassia sp, Areca catechu, Peltophorumpterocarpum, } \\
\text { Phaleria capitata, Cassia siamea, Citrus aurantifolia, and } \\
\text { Ageratum conyzoides) }\end{array}$ & [11] \\
\hline & $\alpha$-Tocopheroland $\delta$-Tocopherol. & HPLC & Morocco & $\begin{array}{l}\text { One multifloral sample (Bupleurum spinosum, } \\
\text { Anethum graveolens, Calendula officinalis, Anacyclus, } \\
\text { Quercus ilex, Eucalyptus, Punica granatum, and Acacia) }\end{array}$ & [20] \\
\hline & $\begin{array}{c}\text { Octanoic, Decanoic, Undecanoic, Dodecanoic, Tridecanoic, } \\
\text { Tetradecanoic, Pentadecanoic, Hexadecanoic, Palmitoleic, } \\
\text { Heptadecanoic, Stearic, Oleic, Linoleic, } \alpha \text {-Linolenic, Arachidic, } \\
\text { Gadoleic, Eicosadienoic, Heneicosanoic, Eicosatrienoic, Arachidonic, } \\
\text { Eicosatrienoic, Behenic, Eicosapentaenoic, Lignocerin, and } \\
\text { Nervonicacid. }\end{array}$ & GC-FID & Morocco & & [20] \\
\hline
\end{tabular}


Table 1. Cont.

\section{Component}

Method Used

Country

Botanical Origin

References

Butanoic, Hexanoic, Octanoic, Decanoic, Undecanoic, Dodecanoic, Tridecanoic, Tetradecanoic, Pentadecanoic, Hexadecanoic,

Heptadecanoic, Octadecanoic, Icosanoic, Heneicosanoic, Docosanoic,

Tricosanoic, Tetracosanoic, (Z)-tetradec-9-enoic, (Z)-pentadec-10-enoic,

(9Z)-hexadec-9-enoic, cis-10-heptadecenoic, (E)-octadec-9-enoi

Z)-octadec-9-enoic, (Z)-icos-11-enoic, (Z)-docos-13-enoic

(Z)-tetracos-15-enoic, octadeca-9,12-dienoic,

(9Z,12Z)-octadeca-9,12-dienoic, Octadeca-6,9,12-trienoic,

GC-MS

Turkey

Z 8Z,11Z,14Z)-icosa-5,8,11,14-tetraenoic, Docosa-13,16-dienoic,

(9Z,12Z,15Z)-octadeca-9,12,15-trienoic,

(11Z14Z17Z)-icosa-11,14,17-trienoic,

(5Z,8Z,11Z,14Z,17Z)-icosa-5,8,11,14,17-pentaenoic, and

Docosa-4,7,10,13,16,19-hexaenoic

Fatty acids

Butanoic acid, Hexanoic acid, Octanoic acid, Decanoic acid,

Undecanoic acid, Dodecanoic acid, Tridecanoic acid, Tetradecanoic

acid, (cis-9) (Z)-tetradec-9-enoic acid, Pentadecanoic acid, (cis-10)

(Z)-pentadec-10-enoic, Hexadecanoic acid, (9Z)-hexadec-9-enoic acid,

Heptadecanoic acid, cis-10-heptadecenoic, Octadecanoic acid

(E)-octadec-9-enoic, (Z)-octadec-9-enoic, (all-trans-9,12)

Octadeca-9,12-dienoic acid, (all-cis-9,12) (9Z,12Z)-octadeca-9,12-dienoic

acid, (all-cis-6,9,12) Octadeca-6,9,12-trienoic acid, (all-cis-9,12,15)

Octadeca-6,9,15-trienoic acid, Icosanoic acid, (cis-11) (Z)-icos-11-enoic acid, (all-cis-11,14,) Icosa-11,14-dienoic acid, (all-cis-8,11,14)

cosa-8,11,14-trienoic acid, (all-cis-11,14,17) Icosa-11,14,17-trienoic acid, (all-cis-5,8,11,14) Icosa-5,8,11,14-tetraenoic acid, (all-cis-5,8,11,14,17)

(cosa-5,8,11,14,17-pentaenoic, Heneicosanoic acid, Docosanoic acid,

(cis-13) (Z)-docos-13-enoic, (all-cis-13,16) Docosa-13,16-dienoic, acid, Tetracosanoic acid, and (cis-15) (Z)-tetracos-15-enoic

Eight monofloral samples (Trifolium pratense,

Gossypium hirsutum, Castanea sativa, Citrus spp.

Helianthus annuus, and Trifolium repens) 
Table 1. Cont.

\begin{tabular}{|c|c|c|c|c|c|}
\hline & Component & Method Used & Country & Botanical Origin & References \\
\hline & $\begin{array}{c}\text { Butyric acid, Caproic acid, Caprylic acid, Capric acid, Undecanoic acid, } \\
\text { Lauric acid, Tridecanoic acid, Myristic acid, Pentadecanoic, Palmitic } \\
\text { acid, Heptadecanoic acid, Stearic acid, Arachidic acid, Heneicosanoic, } \\
\text { Behenic acid, Tricosanoic acid, Lignoceric acid, Myristoleic acid, } \\
\text { cis-Pentadecanoic acid, Palmitoleic acid, cis-Heptadecanoic acid, } \\
\text { Elaidic acid, Oleic acid, cis-Eicosenoic, Erucic acid, Nervonic acid, } \\
\text { Linolelaidic acid, Linoleic acid, g-Linolenic acid, } \\
\text { cis-11,14-Eicosadienoic, cis-8,11,14-Eicosatrienoic acid, Arachidonic } \\
\text { acid, cis-13,16 Docosadienoic, a-Linolenic acid, } \\
\text { cis-11,14,17-Eicosatrienoic acid, cis-5,8,11,14,17-Eicosapentaenoic acid, } \\
\text { and Docosahexaenoic acid }\end{array}$ & GC-FID & Turkey & $\begin{array}{l}\text { In five monofloral samples, the majority of pollen is } \\
\text { Citrus spp. } \\
\text { Secondary pollens belonging to Asteraceae, } \\
\text { Fabaceae, and Brassicaceae families }\end{array}$ & [24] \\
\hline \multirow{3}{*}{ Minerals } & $\mathrm{Ca}, \mathrm{Fe}, \mathrm{K}, \mathrm{Mg}, \mathrm{Na}, \mathrm{Zn}, \mathrm{P}, \mathrm{Pb}, \mathrm{Ni}, \mathrm{Se}, \mathrm{Mn}, \mathrm{Co}, \mathrm{Cu}$, and $\mathrm{Cd}$ & ICP-AES & Morocco & $\begin{array}{l}\text { One multifloral sample (Bupleurum spinosum, } \\
\text { Anethum graveolens, Calendula officinalis, Anacyclus, } \\
\text { Quercus ilex, Eucalyptus, Punica granatum, and Acacia) }\end{array}$ & [20] \\
\hline & $\mathrm{Ca}, \mathrm{Fe}, \mathrm{K}, \mathrm{Mg}, \mathrm{Mn}, \mathrm{Na}, \mathrm{Zn}, \mathrm{P}$, and Se. & ICP-MS & Malaysia & $\begin{array}{c}\text { Four multifloral samples (Mimosa pudica, } \\
\text { Sphagneticolatrilobata, Bidens ilosa, Cassia sp, Areca } \\
\text { catechu, Peltophorumpterocarpum, Phaleria capitata, } \\
\text { Cassia siamea, Citrus aurantifolia, and Ageratum } \\
\text { conyzoides }\end{array}$ & [11] \\
\hline & $\mathrm{Na}, \mathrm{Mg}, \mathrm{K}, \mathrm{Ca}, \mathrm{Mn}, \mathrm{Se}, \mathrm{Fe}, \mathrm{Zn}$, and $\mathrm{Cu}$. & ICP-MS & Serbia & Twelve bee bread samples (not determined) & [31] \\
\hline \multirow{5}{*}{$\begin{array}{l}\text { Polyphenols } \\
\text { composition }\end{array}$} & $\begin{array}{l}\text { Kaempferol-3-O-glycoside, Hydroxycinnamic acid derivative, } \\
\text { Quercetin-3-O-sophoroside, Kaempferol-3-O-derivative, } \\
\text { Hydroxycinnamic acid derivative, Myricetin, Trycetin, Luteolin, } \\
\text { Herbatin-3-O-glycoside, Quercetin-3-O-glycoside, and } \\
\text { Isoramnethin-3-O-glycoside }\end{array}$ & HPLC-DAD & $\begin{array}{l}\text { Romania and } \\
\text { India }\end{array}$ & $\begin{array}{l}\text { Five samples (Brassicaceae, Poaceae, Myrtaceae, } \\
\text { Rutaceae, Asteraceae, Fabaceae, Tiliaceae, Fabaceae, } \\
\text { Rosaceae, Plantaginaceae, Fabaceae, Asteraceae, } \\
\text { Lamiaceae, Salicaceae, Rosaceae, and Fagaceae) }\end{array}$ & [22] \\
\hline & $p$-Coumaric acid, Kaempferol, Chrysin, and Apigenin & HPLC & Lithuania & Nine simples (not determined) & [48] \\
\hline & $\begin{array}{c}\text { Caffeic acid, p-Coumaric acid, Rosmarinic acid, Myricetin, Luteolin, } \\
\text { Quercetin, and Kaempferol }\end{array}$ & HPLC-DAD & Romania & One sample (not determined) & [21] \\
\hline & Naringin, Rutin, and Quercetin. & HPLC & Georgia & Two samples & [49] \\
\hline & Kaempferol and Apigenin & GC/MS & Poland & Three samples. & [50] \\
\hline
\end{tabular}


Table 1. Cont.

\section{Componen}

Kaempferol-O-hexosyl-O-rutinoside, Quercetin-O-hexosyl-O-hexoside,

Quercetin-O-hexosyl-O-hexoside, Methylherbacetrin-O-dihexoside,

Isorhamnetin-O-hexosyl-O-rutinoside, Quercetin-O-pentosyl-hexoside,

Quercetin 3-O-rutinoside, Methylherbacetrin-3-O-rutinoside,

Isorhamnetin-O-pentosyl-hexoside, Isorhamnetin-O-pentosyl-hexoside,

Kaempferol-3-O-rutinoside, Isorhamnetin-O-rhamnoside-hexoside, and Isorhamnetin-3-O-rutinoside

Hesperetin, Quercetin-O-hexosyl-O-rutinosid, Quercetin-diglucoside,

Methyl herbacetin-O-dihexoside, Kaempferol-O-dihexoside, Methyl

herbacetin-O-rutinoside, Isorhamnetin-O-pentosyl-hexosid,

Kaempferol-3-O-rutinoside, Quercetin-3-O-glucoside,

Quercetin-O-malonyl hexoside, Kaempferol-O-malonyl hexoside,

Di-p-coumaroylspermidine, Kaempferol-3-O-rhamnoside, and Isorhamnetin-O-deoxyhexoside

2,5-Dihydroxybenzoic acid, 2-Hydroxycinnamic acid, Caffeic acid,

Catechin, Epicatechin, Chlorogenic acid, Ethyl gallate, Gallic acid,

Isorhamnetin, Kaempferol, Luteolin, Myricetin, Naringin, p-Coumaric

acid, Phlorizin, Propyl gallate, Protocatechuic acid, Quercetin,

Resveratrol, Rutin, Salicylic acid, Sinapic acid, Syringic acid, Trans

$$
\text { ferulic acid }
$$

Myricetin-3-O-rutinoside, Quercetin-O-hexosyl-O-rutinoside

Kaempfrol-O-hexosyl-O-rutinoside,Quercetin-O-hexosyl-O-hexoside,

Isorhamnetin-O-hexosyl-O-rutinoside, Methyl

herbacetrin-O-dihexoside, Myricetin-3-O-glucoside,

Quercetin-O-pentosyl-hexoside, Quercetin-O-hexosyl-rutinoside,

Quercetin 3-O-rutinoside, Methyl herbacetrin-O-hexosyl-rutinoside,

Kaempferol-O-dihexoside, Methyl herbacetrin-3-O-rutinoside, Methyl

herbacetrin-O-dihexoside, Kaempferol-O-hexosyl-rutinoside,

$$
\text { Isorhamnetin-O-pentosyl-hexoside, }
$$

Isorhamnetin-O-hexosyl-rutinoside, Kaempferol-3-O-rutinoside,

Quercetin-3-O-glucoside, Isorhamnetin-o-pentosyl-hexoside,

Isorhamnetin-O-pentosyl-hexoside, Acetyl

kaempferol-O-deoxyhexosyl-hexoside, Methyl

herbacetrin-3-O-glucoside, Laricitrin-3-O-rhamnoside,

Isorhamnetin-3-O-rutinoside, Quercetin-3-O-rhamnoside,

Kaempferol-o-pentosyl-deoxyhexoside, Isorhamnetin-3-O-glucoside,

Acetyl kaempferol-O-hexoside, Kaempferol-3-O-rhamnoside,

Isorhamnetin-3-O-rhamnoside, Acetyl isorhamnetin-O-hexoside
Method Used

Country

Botanical Origin

References
LC-DAD-ESI/MSn

Morocco

One multifloral sample (Bupleurum spinosum

Anethum graveolens, Calendula officinalis, Anacyclus,

Quercus ilex, Eucalyptus, Punica granatum, and Acacia)
Three samples.
Sample 1: Plantago spp. $(47 \%)$

Sample 2: Crepiscapillaris $(60 \%)$

Sample 3: Cytisus striatus (48\%)

LC/DAD/ESI-MS

Portugal

LC-MS/MS

Turkey

Five samples

(not identified). 


\section{The Bioactive Effect of Bee Bread: In Vitro Investigations}

\subsection{Antioxidant Capacity of Bee Bread}

As already mentioned, antioxidant molecules are one of the most important constituents of bee bread. Several studies have evaluated the antioxidant capacity of these molecules using spectrophotometric techniques. Akhir et al. [61] and Othman et al. [12] tested the antioxidant capacities (DPPH, ABTS, and FRAP tests) of different Malaysian bee bread extracts (hexanoic, ethanolic, and distilled water extracts). The authors showed that the solvents used influenced the bioactivity of the bee bread. The most potent extract was the ethanolic extract, followed by the hexanoic extract and then the aqueous extract. Similarly, 15 Colombian bee bread samples were analyzed by Zuluaga et al. [62] for their antioxidant activity. The authors revealed that all the extracts had good antioxidant activity with FRAP and TEAC methods; their total flavonoid content ranged between 1.9 and $4.5 \mathrm{mg}$ equivalent of quercetin $/ \mathrm{g}$, while their total phenolic content ranged between 2.5 and $13.7 \mathrm{mg}$ equivalent of gallic acid/g.

The antioxidant activity of Moroccan bee bread was analyzed in three studies conducted by Bakour et al. [20,63,64] using three different solvents for extraction (ethanol, ethyl acetate, and methanol). The results showed that the antioxidant activity evaluated by three tests-DPPH, ABTS, and reducing power-had the lowest recorded values of $\mathrm{IC}_{50} / \mathrm{EC}_{5050}$ forthe ethanolic extract, followed by the methanolic extract and then by the ethyl acetate extract.

Several studies published between 2004 and 2020 demonstrated the antioxidant capacity of European bee bread in vitro. The results showed that all evaluated samples had potent antioxidant activities [50,65-68] (Table 2).

\subsection{The Antitumoral Effect of Bee Bread}

The antitumor activity of bee bread has been evaluated in vitro in two studies, the first performed by Markiewicz-Żukowska et al. [50], in which different ethanolic extracts of bee bread samples collected from Poland were tested for the viability of the glioblastoma cell line (U87MG) after $24 \mathrm{~h}, 48 \mathrm{~h}$, and $72 \mathrm{~h}$. The results showed that bee bread ethanolic extract reduced the viability of cancer cells with percentages ranging from $49 \%$ to $66 \%$. This inhibitory effect appeared mainly after the passage of $72 \mathrm{~h}$ of contact.

The second study is that of Sobral et al. [46], who evaluated the antitumor activity of bee bread from northeastern Portugal against different human tumor cell lines-NCIH460 (non-cellular lung cancer), HepG2 (carcinoma hepatocellular), HeLa (cervical cancer), MCF-7 (breast adenocarcinoma) — and also against non-tumor liver cells (porcine liver cells, PLP2). The bee bread samples showed low to moderate cytotoxicity ranging from $>400$ to $68 \mu \mathrm{g} / \mathrm{mL}$; however, none of the bee bread samples showed toxicity against normal cells (Table 2).

\subsection{Hypotensive Effect}

The hypotensive effect of bee bread was evaluated by Nagai et al. [69] using enzymatic hydrolysates from bee bread prepared by three proteases: pepsin, trypsin, and papain. The obtained hydrolysates showed inhibitory activities for the angiotensin I converting enzyme of $1.48 \mathrm{mg}$ protein/mL obtained by the hydrolyzate of pepsin, $2.16 \mathrm{mg}$ protein $/ \mathrm{mL}$ obtained by the hydrolyzate of trypsin, and $5.41 \mathrm{mg}$ protein/mL obtained by papain hydrolysate (Table 2).

\subsection{The Inhibition Effect of Carbohydrate-Hydrolyzing Enzymes}

The good management of diabetes necessitates the control of the approach to the first line of treatment, such as discovering new agents with a high inhibition potential for carbohydrate-hydrolyzing enzymes. In vitro studies have demonstrated the ability of bee bread methanolic extract to inhibit alpha-amylase with an $\mathrm{IC}_{50} \%$ of $3.57 \mathrm{mg} / \mathrm{mL}$ [67]. The techniques of molecular docking, ultraviolet absorption, and fluorescence quenching tests have demonstrated that the bee bread contains functional fatty acids thatinteract with the 
amino acid residues of hydrolyzing enzymes through hydrogens bonds and vander Waals interactions [70]. Bee bread is a complex product with a high flavonoid content; flavonoids are known for their capacity to embed in the active site of the enzyme by bond and alkyl interactions, which are facilitated through the diverse methyl and hydroxyl groups that characterize the flavonoid's structure [71]. The ability of bee bread to control metabolism disorders through the inhibition of carbohydrate-hydrolyzing enzymes has been confirmed by in vivo studies detailing the pharmacological effects of bee bread, as shown in the in vivo investigations section (Table 2). 
Table 2. In vitro studies of bee bread from different countries in the world.

\begin{tabular}{|c|c|c|c|c|c|c|c|}
\hline Country & $\begin{array}{l}\text { Functional } \\
\text { Effect }\end{array}$ & $\begin{array}{l}\text { The Majority of Pollen Grains } \\
\text { Identified in Bee Bread (BB) }\end{array}$ & Extraction Used & Concentration & Extraction Time & Results Obtained & References \\
\hline Malaysia & Antioxidant & One sample, not identified & $\begin{array}{c}\text { Hexane and } 70 \% \text { ethanol } \\
\text { using Soxhlet } \\
\text { apparatus }\end{array}$ & $\begin{array}{l}\text { Sixty gramsof sample } \\
\text { extracted with } 300 \mathrm{~mL} \text { of } \\
\text { solvent }\end{array}$ & $2 \mathrm{~h}$ & $\begin{array}{l}\text { DPPH value of ethanolic extract (\%): } 93.60 \pm 0.03 \\
\text { DPPH value of hexanic extract (\%): } 83.81 \pm 0.05 \\
\text { ABTS value of ethanolic extract (\%): } 97.95 \pm 0.01 \\
\text { ABTS value of hexanicextract (\%): } 71.23 \pm 0.01 \\
\text { FRAP value of ethanolic extract (mM FE/g): } 0.85 \pm 0.01 \\
\text { FRAP value of hexanic extract (mM FE/g): } 2.41 \pm 0.02\end{array}$ & [61] \\
\hline Portugal & Antioxidant & $\begin{array}{c}\text { Three samples } \\
\text { Sample 1: Plantago sp. } \\
\quad(47 \%) \\
\text { Sample 2: Crepis capillaris }(60 \%) \\
\text { Sample 3: Cytisus striatus }(48 \%)\end{array}$ & $\mathrm{EtOH} / \mathrm{H}_{2} \mathrm{O}(80: 20, v / v)$ & $\begin{array}{l}\text { Two grams of sample was } \\
\text { extracted with } 40 \mathrm{~mL} \text { of } \\
\text { EtOH/ } \mathrm{H}_{2} \mathrm{O}(80: 20, v / v)\end{array}$ & & $\begin{array}{l}\text { Total phenolic content value ranging between } 3.2 \text { and } \\
3.8 \pm 0.1 \mathrm{mg} \mathrm{GAE} / \mathrm{g} \\
\text { Total flavonoid content value ranging between } 0.6 \text { and } \\
2.7 \mathrm{mg} \mathrm{QE} / \mathrm{g}\end{array}$ & [47] \\
\hline Ukraine & Antioxidant & Five samples & $\begin{array}{c}\text { Methanol/water solution } \\
(70 \%, v / v)\end{array}$ & $\begin{array}{l}\text { A total of } 0.1 \mathrm{~g} \text { of sample } \\
\text { in } 5 \mathrm{~mL} \text { of } \\
\text { methanol/water solution } \\
\quad(70 \%, v / v)\end{array}$ & & $\begin{array}{l}\text { Total phenolic content value ranging between } 12.36 \text { and } \\
25.44 \mathrm{mg} \text { GAE/g } \\
\text { Total flavonoid content ranging between } 13.56 \text { and } \\
18.24 \mu \mathrm{g} \text { QE/g }\end{array}$ & [72] \\
\hline Lithuania & Antioxidant & Four samples & Not mentioned & Not mentioned & $\begin{array}{l}\text { Not } \\
\text { mentioned }\end{array}$ & $\begin{array}{l}\text { Total phenolic content value ranging between } 306 \text { and } \\
\quad 394 \mathrm{mg} \text { GAE } / 100 \mathrm{~g} \\
\text { DPPH radical scavenging abilities ranged between } 85 \\
\text { and } 93 \%\end{array}$ & [73] \\
\hline
\end{tabular}


Table 2. Cont.

\begin{tabular}{|c|c|c|c|c|c|c|c|}
\hline Country & $\begin{array}{l}\text { Functional } \\
\text { Effect }\end{array}$ & $\begin{array}{l}\text { The Majority of Pollen Grains } \\
\text { Identified in Bee Bread (BB) }\end{array}$ & Extraction Used & Concentration & Extraction Time & Results Obtained & References \\
\hline Lithuania & Antioxidant & One sample (not identified) & $\begin{array}{l}\text { Three types of extraction: } \\
\text { Hot distilled water } \\
\text { Distilled water } \\
\text { Ethanol }\end{array}$ & $\begin{array}{c}\text { Extract } 1: 3 \mathrm{~g} \text { of } \mathrm{BB} \text { was } \\
\text { extracted by boiling with } \\
10 \text { volumes of distilled } \\
\text { water. } \\
\text { Extract } 2: 3 \mathrm{~g} \text { of BB was } \\
\text { extracted by shaking with } \\
10 \text { volumes of distilled } \\
\text { water. } \\
\text { Extract } 3: 3 \mathrm{~g} \text { of BB with } \\
10 \text { volumes of ethanol }\end{array}$ & $\begin{array}{l}\text { Extract } 1: 1 \mathrm{~h} \\
\text { Extract 2: } 1 \text { day } \\
\text { Extract 3: } 1 \text { day }\end{array}$ & $\begin{array}{c}\text { Superoxide anion radical scavenging abilities ranged } \\
\text { between } 9.92 \% \text { and } 100 \% \\
\text { Hydroxyl radical scavenging abilities ranged between } \\
9.75 \text { and } 100 \% \\
\text { DPPH radical scavenging abilities ranged between } 10.5 \\
1 \pm 0.2 \% \text { and } 98.7 \pm 10.2 \% \\
\text { Antioxidant abilities ranged between } \\
0.0181 \pm 0.002 \text { and } 1.352 \pm 10.036 \%\end{array}$ & {$[68]$} \\
\hline Morocco & Antioxidant & One sample (not identified) & Ethanolic extraction $(70 \%)$ & $\begin{array}{l}\text { One gram of BB } \\
\text { macerated in } 20 \mathrm{~mL} \\
\text { of ethanol }(70 \%)\end{array}$ & 1 week & $\begin{array}{c}\text { Polyphenol content was } 14.88 \pm 0.98 \mathrm{mg} \mathrm{GAE} / \mathrm{g} \text {, } \\
\text { flavonoid content was } 1.67 \pm 0.12 \mathrm{mg} \mathrm{QE} / \mathrm{g} \text {, total } \\
\text { antioxidant capacity was } 143.78 \pm 11.38 \mathrm{mg} \text { AAE } / \mathrm{g} \text {, } \\
\mathrm{IC}_{50} \text { of DPPH was } 0.05 \pm 0.01 \mathrm{mg} / \mathrm{mL}, \mathrm{IC}_{50} \text { of ABTS } \\
\text { was } 0.08 \pm 0.05 \mathrm{mg} / \mathrm{mL} \text {, and reducing power was } \\
0.05 \pm 0.04 \mathrm{mg} / \mathrm{mL}\end{array}$ & [63] \\
\hline Morocco & Antioxidant & $\begin{array}{l}\text { One multifloral sample ( } 35 \% \\
\text { Anethum graveolens, } 24 \% \text { Quercus } \\
\text { ilex, } 16 \% \text { Eucalyptus, and } 25 \% \\
\text { other pollens) }\end{array}$ & Hydromethanolic extract & $\begin{array}{c}\text { One gram of BB extracted } \\
\text { twice with } \\
30 \mathrm{~mL} \text { of a mixture of } \\
\text { methanol/water }(80: 20 \\
v / v)\end{array}$ & $60 \mathrm{~min}$ & $\begin{array}{c}\text { Total antioxidant capacity: } 143 \pm 22 \\
\text { DPPH: } 0.98 \pm 0.06 \\
\text { ABTS: } 0.50 \pm 0.04 \\
\text { Reducing power: } 0.19 \pm 0.03\end{array}$ & [20] \\
\hline Ukraine & Antioxidant & Five samples (not determined) & $\begin{array}{c}\text { BB was extracted with } \\
\text { ethanol }\end{array}$ & $\begin{array}{l}\text { A total of } 0.1 \mathrm{~g} \text { of } \mathrm{BB} \text { was } \\
\text { extracted with } 20 \mathrm{~mL} \text { of } \\
\text { ethanol }(80 \%)\end{array}$ & $2 \mathrm{~h}$ & $\begin{array}{c}\text { Total polyphenol content ranged between } \\
12.36 \pm 0.34 \mathrm{mg} \text { GAE } / \mathrm{g} \text { and } 25.44 \pm 0.22 \mathrm{mg} \mathrm{GAE} / \mathrm{g} \\
\text { Total flavonoid content ranged between } \\
13.56 \pm 0.04 \mu \mathrm{g} \mathrm{QE} / \mathrm{g} \text { and } \\
15.35 \pm 0.09 \mu \mathrm{g} \mathrm{QE} / \mathrm{g} \\
\text { The best value of the } \mathrm{DPPH} \text { test was } 15.78 \mathrm{mg} \text { TEAC/g } \\
\text { The value for reducing power was } 250 \mathrm{mg} \text { TEAC/g }\end{array}$ & [66] \\
\hline Lithuania & Antioxidant & Nine samples (not determined) & $\begin{array}{l}\text { Extraction of phenolic } \\
\text { compounds using } \\
\text { distilled water, methanol, } \\
\text { and diethyl ether }\end{array}$ & $\begin{array}{l}\text { Fifty grams of BB was } \\
\text { extracted with } 250 \mathrm{~mL} \text { of } \\
\text { distilled water and } 250 \\
\text { mL of methanol; the } \\
\text { residue obtained was } \\
\text { dissolved in } 5 \mathrm{~mL} \text { of } \\
\text { distilled water and } \\
\text { extracted with } 5 \mathrm{~mL} \text { of } \\
\text { diethyl ether (three times) }\end{array}$ & $\begin{array}{c}\text { Not } \\
\text { determined }\end{array}$ & $\begin{array}{l}\text { DPPH values ranged between } 64.2 \pm 1.8 \% \text { and } \\
93.9 \pm 0.6 \% \\
\text { ABTS values ranged between } 76.5 \pm 0.2 \% \text { and } \\
94.8 \pm 0.5 \%\end{array}$ & [48] \\
\hline
\end{tabular}


Table 2. Cont.

\begin{tabular}{|c|c|c|c|c|c|c|c|}
\hline Country & $\begin{array}{l}\text { Functional } \\
\text { Effect }\end{array}$ & $\begin{array}{l}\text { The Majority of Pollen Grains } \\
\text { Identified in Bee Bread (BB) }\end{array}$ & Extraction Used & Concentration & Extraction Time & Results Obtained & References \\
\hline Morocco & Antioxidant & One sample (not identified) & $\begin{array}{l}\text { BB was extracted with } \\
\text { ethyl acetate }\end{array}$ & - & $\begin{array}{c}\text { Not } \\
\text { determined }\end{array}$ & $\begin{array}{c}\text { Polyphenols: } 27.27 \pm 0.38 \mathrm{mg} \mathrm{EqGA} / \mathrm{g} \\
\text { Flavonoids: } 5.29 \pm 0.27 \mathrm{mg} \mathrm{EqQ} / \mathrm{g} \\
\text { TAC: } 65.44 \pm 6.34 \mathrm{mg} \mathrm{EqAA} / \mathrm{g} \\
\mathrm{IC}_{50} \text { of ABTS: } 1.52 \pm 0.021 \mathrm{mg} / \mathrm{mL} \\
\mathrm{IC}_{50} \text { of DPPH: } 0.43 \pm 0.02 \mathrm{mg} / \mathrm{mL} \\
\text { EC }_{50} \text { of RP:0.71 } \pm 0.05 \mathrm{mg} / \mathrm{ml}\end{array}$ & [64] \\
\hline Poland & Antitumoral & Three samples (not identified) & $\begin{array}{l}\text { Ethanolic } \\
\text { Extract }\end{array}$ & $\begin{array}{l}\text { Twenty grams were } \\
\text { extracted with } 80 \mathrm{~g} \text { of } 95 \% \\
(v / v) \text { ethanol and } \\
\text { re-extracted with } 40.0 \mathrm{~g} \text { of } \\
95 \%(v / v) \text { ethanol }\end{array}$ & $12 \mathrm{~h}$ & $\begin{array}{c}\text { Polyphenolic content: ranged between } 33.43 \pm 0.7 \text { and } \\
\qquad 36.52 \pm 0.6 \mathrm{mg} \mathrm{GAE} / \mathrm{g} \\
\text { Antioxidant activity: ranged between } 0.56 \pm 0.06 \text { and } \\
\quad 1.11 \pm 0.09 \mathrm{mmol} / \mathrm{L} \\
\text { The cytotoxicity of BB was studied using a } \\
\text { glioblastoma cell line (U87MG), the results indicated a } \\
\text { time-dependent inhibitory } \\
\text { effect on the viability of U87MG cells treated with BB. } \\
\text { The cell viability was decreased to } 49-66 \% \text { after } 72 \mathrm{~h} \text {. }\end{array}$ & [50] \\
\hline Turkey & $\begin{array}{l}\alpha \text {-amylase } \\
\text { inhibition }\end{array}$ & $\begin{array}{l}\text { One sample; predominant } \\
\text { pollen was Trifolium pretense } \\
(70.39 \%), \text { important minor } \\
\text { pollen }(3-15 \%) \text { presented by } \\
\text { Cistaceae, Asteraceae, Rosaceae, } \\
\text { and others }(<3 \%)\end{array}$ & $\begin{array}{l}\text { BB was frozen, powdered, } \\
\text { and then extracted with } \\
\text { methanol }\end{array}$ & $\begin{array}{l}\text { Two grams was mixed } \\
\text { with } 10 \mathrm{~mL} \text { of methanol }\end{array}$ & $\begin{array}{c}48 \mathrm{~h} \\
\text { under stirring }\end{array}$ & $\begin{array}{c}\mathrm{IC}_{50} \text { of } \alpha \text {-amylase inhibition was } 3.57 \pm 0.01 \text {, better } \\
\text { than acarbose }\left(\mathrm{IC}_{50}=5.93 \pm 0.01\right)\end{array}$ & [67] \\
\hline Lithuania & $\begin{array}{l}\text { Angiotensin } \\
\text { I-converting } \\
\text { enzyme } \\
\text { inhibition }\end{array}$ & One sample (not determined) & $\begin{array}{l}\text { Preparation of enzymatic } \\
\text { hydrolysates from bee } \\
\text { bread by digestion with } \\
\text { three kinds of enzymes } \\
\text { (pepsin, trypsin, and } \\
\text { papain) }\end{array}$ & $\begin{array}{c}10 \% \\
\text { (Pepsin hydrolysate) } \\
10 \% \\
\text { (Trypsin hydrolysate), } \\
4 \% \\
\text { (Papain hydrolysate) }\end{array}$ & Not determined & $\begin{array}{l}\mathrm{IC}_{50} \text { of angiotensin I-converting enzyme inhibition of } \\
\text { pepsin hydrolysate: } 1.48 \mathrm{mg} \text { protein } / \mathrm{mL} \\
\mathrm{IC}_{50} \text { of angiotensin I-converting enzyme inhibition of } \\
\text { trypsin hydrolysate: } 2.16 \mathrm{mg} \text { protein } / \mathrm{mL} \\
\mathrm{IC}_{50} \text { of angiotensin I-converting enzyme inhibition of } \\
\text { papain hydrolysate: } 5.41 \mathrm{mg} \text { protein } / \mathrm{mL}\end{array}$ & [69] \\
\hline
\end{tabular}


Table 2. Cont.

\begin{tabular}{|c|c|c|c|c|c|c|c|}
\hline Country & $\begin{array}{c}\text { Functional } \\
\text { Effect }\end{array}$ & $\begin{array}{l}\text { The Majority of Pollen Grains } \\
\text { Identified in Bee Bread (BB) }\end{array}$ & Extraction Used & Concentration & Extraction Time & Results Obtained & References \\
\hline Portugal & $\begin{array}{l}\text { Antitumor } \\
\text { activity }\end{array}$ & Six samples, not determined & $\begin{array}{c}\text { BB was lyophilized and } \\
\text { extracted twice with } \\
\text { methanol:water }(80: 20 \\
v / v)\end{array}$ & $\begin{array}{c}\text { One gram of } \mathrm{BB} \text { in } 30 \mathrm{~mL} \\
\text { of solvent }\end{array}$ & $1 \mathrm{~h}$ & $\begin{array}{c}\text { Three samples of BB hadcytotoxic activity against } \\
\text { MCF-7 (breast adenocarcinoma), IG } \text { I }_{50} \text { values were: } \\
186 \pm 6 \mu \mathrm{g} / \mathrm{mL} ; 84 \pm 3 \mu \mathrm{g} / \mathrm{mL} \text {; and } 164 \pm 4 \mu \mathrm{g} / \mathrm{mL} \text {. } \\
\text { Three samples of BB had cytotoxic activity against } \\
\text { NCI-H460 (non-small cell lung cancer), IG } \mathrm{I}_{50} \text { values } \\
\text { were: } 253 \pm 10 \mu \mathrm{g} / \mathrm{mL} ; 85 \pm 5 \mu \mathrm{g} / \mathrm{mL} \text {; and } \\
68 \pm 8 \mu \mathrm{g} / \mathrm{mL} \text {. } \\
\text { Four samples of BB hadcytotoxic activity against HeLa } \\
\text { (cervical carcinoma), } \\
\text { IG } 50 \text { values were:345 } \pm 13 \mu \mathrm{g} / \mathrm{mL} ; 225 \pm 12 \mu \mathrm{g} / \mathrm{mL} ; \\
209 \pm 21 \mu \mathrm{g} / \mathrm{mL} \text { and } 366 \pm 7 \mu \mathrm{g} / \mathrm{mL} \text {. } \\
\text { One sample of BB had cytotoxic activity against HepG2 } \\
\text { (hepatocellular carcinoma), } \\
\text { IG }{ }_{50} \text { value was } 67 \pm 1 \mu \mathrm{g} / \mathrm{mL} \text {. } \\
\text { None of the BB samples had toxicity against non-tumor } \\
\text { liver cells (porcine liver cells, PLP2). }\end{array}$ & [46] \\
\hline Turkey & Antioxidant & $\begin{array}{c}\text { One sample; predominant } \\
\text { pollen was Trifolium pretense } \\
\text { (70.39\%), important minor } \\
\text { pollen (3-15\%) presented by } \\
\text { Cistaceae, Asteraceae, Rosaceae, } \\
\text { and others }(<3 \%)\end{array}$ & $\begin{array}{l}\text { BB was frozen, powdered, } \\
\text { and then extracted with } \\
\text { methanol }\end{array}$ & $\begin{array}{l}\text { Two grams was mixed } \\
\text { with } 10 \mathrm{~mL} \text { of methanol }\end{array}$ & $\begin{array}{l}48 \mathrm{~h} \text { under } \\
\text { stirring }\end{array}$ & $\begin{array}{c}\text { Total phenolics: } 6.93 \pm 0.09 \mathrm{mg} \mathrm{GAE} / \mathrm{g} \\
\text { Total flavonoids: } 2.27 \pm 0.05 \mathrm{mg} \mathrm{QE} / \mathrm{g} \\
\text { Antioxidant capacity: } 83.62 \pm 0.33 \mu \mathrm{mol} \mathrm{FeSO}{ }_{4} 7 \\
\mathrm{H}_{2} \mathrm{O} / \mathrm{g} \text { sample }\end{array}$ & [67] \\
\hline Malaysia & Antioxidant & Three samples, not identified & $\begin{array}{l}\text { Distilled water or ethanol } \\
70 \%\end{array}$ & $\begin{array}{l}\text { Fifty grams of bee bread } \\
\text { extracted with } 10 \text { volumes } \\
\text { of distilled water or } 70 \% \\
\text { of ethanol }\end{array}$ & $72 \mathrm{~h}$ & $\begin{array}{c}\text { DPPH value of aqueous extract ranging between } \\
2.86 \% \text { and } 8.95 \% \\
\text { DPPH value of ethanolic extract ranging between } \\
72.04 \% \text { and } 79.34 \% \\
\text { FRAP value of aqueous extract ranging between } \\
0.94 \mathrm{mmol} \mathrm{Fe}^{2} / \mathrm{L} \text { and } 1 \mathrm{mmol} \mathrm{Fe}^{2} / \mathrm{L} \\
\text { FRAP value of ethanolic extract ranging between } \\
1.07 \mathrm{mmol} \mathrm{Fe} / \mathrm{L} \text { and } 1.08 \mathrm{mmol} \mathrm{Fe} / \mathrm{L} \\
\text { Total flavonoid content of aqueous extract ranging } \\
\text { between } 2.88 \mathrm{mg} \mathrm{QE} / \mathrm{g} \text { and } 3.92 \mathrm{mg} \mathrm{QE} / \mathrm{g} \\
\text { Total flavonoid content of ethanolic extract ranging } \\
\text { between } 16.48 \mathrm{mg} \mathrm{QE} / \mathrm{g} \text { and } 26.57 \mathrm{mg} \mathrm{QE} / \mathrm{g} \\
\text { Total phenolic content of aqueous extract ranging } \\
\text { between } 14.19 \mathrm{mg} \mathrm{GAE} / \mathrm{g} \text { and } 15.38 \mathrm{mg} \mathrm{GAE} / \mathrm{g} \\
\text { Total phenolic content of ethanolic extract ranging } \\
\text { between } 21.32 \mathrm{mg} \mathrm{GAE} / \mathrm{g} \text { and } 22.54 \mathrm{mg} \mathrm{GAE} / \mathrm{g}\end{array}$ & [12] \\
\hline
\end{tabular}




\subsection{Probiotic Properties of Bee Bread}

Probiotics are defined by the Food and Agriculture Organization and the World Health Organization as "live microorganisms that when administered in adequate amounts confer a health benefit on the host" [74]. Human probiotic strains frequently belong to the Lactobacilli, Bifidobacteria lactococcus, Streptococcus, and Enterococcusgenera, and some yeast strains belonging to the genus Saccharomyces [75]. Recently, the field of study on probiotics has gained great scientific and public interest due to their beneficial effects in the treatment of several human diseases, notably inflammatory bowel diseases, gut infections, allergy, asthma pulmonary infections, and even psychiatric illnesses [76,77]. A recent study suggested that probiotics could be beneficial in the framework of COVID-19 infection through their immunomodulatory effect [78]. Indeed, the relationship between probiotic bacteria and human well-being has been well established and, as a result, consumers are becoming more concerned and require more functional food in their diet, especially fermented food and beverages [79].

In a similar context, bee bread is a natural probiotic-rich product that contains a different and complex spectrum of microorganisms, such as bacteria and fungi, involved in the bee bread production process through bee pollen lactic fermentation [80]. Indeed, Toutiaee et al. [81] reported the isolation of a Bacillus species with probiotic properties.

The microbial composition with probiotic properties of bee bread confers interesting therapeutic effects to this product. Khalifa et al. [82] in their review study suggested that bee bread exhibits a remarkable hypolipidemic effect through the cholesterol-lowering factors produced by Lactobacillus bacteria. Moreover, the presence of Lactobacillus bacteria and fructophilic lactic acid bacteria in bee bread provides a promising source of compounds with high techno-functional properties that are used in the food industry as a food preservative or in functional culture for the production of fermented food at an industrial scale.

\subsection{Antimicrobial Activity of Bee Bread}

Bee bread from different regions of Morocco was evaluated by Abouda et al. [83] for antibacterial activity against the following bacteria: Staphylococcus aureus, Bacillus cereus, Pseudomonas aeruginosa, and Escherichia coli. The results showed that all bee bread samples exhibited strong antimicrobial activities against the bacterial strains, with greater sensitivity to Gram-positive bacteria than Gram-negative bacteria.

Baltrušaitytè et al. [65] tested four samples of bee bread against Staphylococcus aureus and Staphylococcus epidermidis. The results obtained after the neutralization of the product and its treatment with catalase revealed that the samples of bee bread had non-peroxide antibacterial activity. Similarly, Ivanišov et al. [66] showed that samples of bee bread from five regions of Ukraine possessed antimicrobial activities against four bacterial strains, two Gram-positive-Bacillus thuringiensis and Staphylococcus aureus-and two Gram-negativeEscherichia coli and Salmonella enterica. The findings revealed that the minimum inhibitory concentrations varied between $6.40 \mu \mathrm{g} \mathrm{mL}^{-1}$ and $25.58 \mu \mathrm{g} \mathrm{mL}{ }^{-1}$.

The hydromethanolic extract of Moroccan multifloral bee bread (35\% Anethum graveolens, 24\% Quercus ilex, 16\% Eucalyptus, and 25\% other pollens) was evaluated against six bacterial strains (Bacillus cereus, Staphylococcus aureus, Escherichia coli, Enterobacter cloacae, Salmonella typhimurium, and Listeria monocytogenes), and it was shown that the minimum inhibitory concentration (MIC) and minimum bactericidal concentration (MBC) values ranged between $0.04 \mathrm{mg} / \mathrm{mL}$ and $0.25 \mathrm{mg} / \mathrm{mL}$ and between 0.08 and $0.35 \mathrm{mg} / \mathrm{mL}$, respectively. The bee bread sample was also effective against Aspergillus fumigatus, Aspergillus ochraceus, Aspergillus niger, Penicillium funiculosum, Penicillium ochrochloron, and Penicillium verrucosum var. cyclopium. The obtained MIC and MBC values ranged between 0.35 and $1 \mathrm{mg} / \mathrm{mL}$ and between 0.70 and $1.40 \mathrm{mg} / \mathrm{mL}$, respectively [20] (Table 3).

In a study conducted by Didaras et al. [84], it was reported that the aqueous extract of Greek bee bread was effective against Gram-positive bacteria (MIC values ranging between $3.9 \mathrm{mg} / \mathrm{mL}$ and $48 \mathrm{mg} / \mathrm{mL}$ ) and against Gram-negative bacteria (MIC values ranging between $7.8 \mathrm{mg} / \mathrm{mL}$ and $90.4 \mathrm{mg} / \mathrm{mL}$ ). It has also been shown that bee bread ethanolic extracts 
$(70 \%, 95 \%, 80 \%$, and $50 \%)$ have strong antibiotic activity against Gram-positive bacteria (Bacillus cereus, Clostridium perfringens, Staphylococcus aureus, Bacillus Subtilis, methicillinsusceptible Staphylococcus aureus, Staphylococcus epidermidis, and Listeria monocytogene), Gram-negative bacteria (Haemophilus influenza, Klebsiella pneumonia, Salmonella enteric, Escherichiacoli, Shigella, Salmonella typhi, and Pseudomonas aeruginosa)and fungi (Candida albicans, Aspergillus niger, Candida glabrata, Candida tropicalis, Aspergillus clavatus, Aspergillus flavus, Aspergillus versicolor, Penicillium expansum, Penicillium chrysogenum, and Penicillium griseofulvum) [52,85-88].

In most studies, it seems that Gram-positive bacteria are, in general, more susceptible to bee bread extract than Gram-negative bacteria. This may be due to the cytoplasmic membrane of Gram-negative bacteria, which contains less anionic phospholipids than Gram-positive bacteria; this particular composition is the cause of the resistance of certain Gram-negative bacteria to antibiotics [89].

Until now, the antiviral property of bee bread was revealed only in a study published by Didaras et al. [90] against the EV-D68 virus. The results showed promising $\mathrm{IC}_{50}$ values, ranging between 0.048 and $5.45 \mathrm{mg} / \mathrm{mL}$, and $\mathrm{CC}_{50}$ values ranging between 0.17 and $8.60 \mathrm{mg} / \mathrm{mL}$. Numerous reports have suggested that the antiviral effect of bee products is attributed to their content of polyphenols, such as caffeic acid, chrysin, galangin, and rutin [91,92]. Recently, in silico studies have shown that flavonoids may inhibit SARS-CoV-2 $[93,94]$.

\subsection{Proposed Mechanisms of Antimicrobial Action}

The investigation of new, safer, and more effective antibacterial molecules from food and food by-products has attracted the interest of many researchers worldwide. Owing to their hydroxyl groups $(\mathrm{OH})$, phenolic compounds and some antioxidant molecules interact with the bacterial cell membrane by hydrogen bonding and achieve their antibacterial action by two possible combined mechanisms. The first mechanismis through the disruption of the bacterial membrane structure and thus the loss of the cellular contents [95]. The second mechanism depends on the delocalization of electrons, which results in the depolarization of the cell membrane and the reduction in the $\mathrm{pH}$ gradient across the membrane, and thus a reduction in ATP synthesis [96]. The antibacterial efficacy of phenolic compounds is mainly influenced by the relative position of the hydroxyl group on the phenolic nucleus of each antioxidant molecule [95].

Bee bread contains different valuable molecules (Table 1) with potent bactericidal properties. Several studies have shown that flavonoids induce their antibacterial actions by targeting different pathways and mechanisms, including the inhibition of nucleic acid synthesis, the disruption of cytoplasmic membrane function, the modification of cell membrane permeability, and the interaction with some vital bacterial enzymes. A recent study conducted by Wang and coworkers demonstrated that quercetin, a ubiquitous flavonol, exerts its bactericidal effect on Escherichia coli and Staphylococcusaureusbydamaging the bacterial wall and membrane structure as well as by inhibiting bacterial protein synthesis [97]. Furthermore, quercetin inhibits bacterial energy metabolism and DNA synthesis [98]. It was shown that kaempferol, a flavonol compound commonly found in bee bread, inhibits DNA PriA helicase and decreases ATPase activity in Staphylococcus aureus, which suggests its application as a natural component in the development of new active antibiotics against Staphylococcus aureus [99]. The antibacterial effect of other flavonoids, such as apigenin, has also been evaluated. Yu et al. [100] reported that apigenin inhibits RNA polymerase and DNA gyrase in Staphylococcus aureus.

In addition to phenolic compounds, organic acids (aromatic and aliphatic) have been reported to possess bacteriostatic and bactericidal effects [101]. Organics acids can permeate facilely through the bacterial membrane; once inside the cells, they release protons $\left(\mathrm{H}^{+}\right)$, decreasing intracellular $\mathrm{pH}$, attacking macromolecules, and destabilizing bacterial walls [102]. The antibacterial properties of individual organic acids, such as gluconic, acetic, and formic acids, were widely investigated by several researchers. It was shown in one 
study that gluconic acid, a major organic acid present in bee bread, caused membrane cell depolarization and disrupted membrane integrity [103]. Moreover, a recent study showed that acetic acid is implicated in the sabotage of bacterial gene expression, including DNA replication enzymes, the elongation factors TU and GOS, polymerase alpha subunit, C-acetyltransferase 1OS, and chaperone proteins [104]. Besides its antibacterial effect, acetic acid exhibited a high inhibition of Conidia germination and aflatoxin production [105]. Finally, the antimicrobial efficacy of bee bread extracts is potentially due to the interaction between its active ingredients and microbial cells through one or more different mechanisms of action (Figure 2). Current data suggest that bee bread could be used as a promising antibiotic and natural food preservative ingredient. 
Table 3. Antimicrobial and antiviral activities of bee bread.

\begin{tabular}{|c|c|c|c|c|c|c|}
\hline Effect & Country & $\begin{array}{l}\text { Type of the } \\
\text { Study }\end{array}$ & Bacteria/Fungi/Virus Strains & Extract Used & Key Results & References \\
\hline Antibacterial & \multirow[t]{2}{*}{ Morocco } & \multirow[t]{2}{*}{ In vitro } & $\begin{array}{c}\text { Gram-positive bacteria: } \\
\text { Bacillus cereus (food isolate), } \\
\text { Staphylococcus aureus (ATCC 6538), and } \\
\text { Listeria monocytogenes (NCTC } \\
\text { 7973) } \\
\text { Gram-negative bacteria: } \\
\text { Escherichia coli (ATCC 35210), } \\
\text { Enterobacter cloacae (human isolate), and } \\
\text { Salmonella typhimurium (ATCC13311) }\end{array}$ & \multirow{2}{*}{$\begin{array}{l}\text { Hydromethanolic } \\
\text { extract } \\
\text { One gramof BB extracted } \\
\text { twice with } \\
30 \mathrm{~mL} \text { of a mixture of } \\
\text { methanol/water }(80: 20 \\
v / v) \text { for } 60 \mathrm{~min}\end{array}$} & $\begin{array}{c}\text { Gram-positive bacteria: } \\
\text { MIC values ranging } \\
\text { between } 0.4 \text { and } 0.175 \mathrm{mg} / \mathrm{mL} \\
\text { MBC values ranging } \\
\text { between } 0.08 \text { and } 0.35 \mathrm{mg} / \mathrm{mL} \\
\text { Gram-negative bacteria: } \\
\text { MIC values ranging } \\
\text { between } 0.175 \text { and } 0.25 \mathrm{mg} / \mathrm{mL} \\
\text { MBC values were } 0.35 \mathrm{mg} / \mathrm{mL} \text { for all strains }\end{array}$ & \multirow[t]{2}{*}{ [20] } \\
\hline Antifungal & & & $\begin{array}{l}\text { Aspergillus fumigatus (ATCC 1022), Aspergillus } \\
\text { ochraceus (ATCC 12066), Aspergillus niger } \\
\text { (ATCC 6275), Penicillium funiculosum } \\
\text { (ATCC 36839), Penicillium ochrochloron (ATCC } \\
\text { 9112), and Penicillium verrucosum var. } \\
\text { cyclopium (food isolate) }\end{array}$ & & $\begin{array}{c}\text { MIC values ranged between } 0.35 \mathrm{mg} / \mathrm{mL} \text { and } \\
1 \mathrm{mg} / \mathrm{mL} \text {, and MFC values } \\
\text { ranged } \\
\text { between } 0.70 \mathrm{mg} / \mathrm{mL} \text { and } 1.40 \mathrm{mg} / \mathrm{mL}\end{array}$ & \\
\hline Antibacterial & Morocco & In vitro & $\begin{array}{c}\text { Gram-positive bacteria: } \\
\text { Staphylococcus aureus, three strains of } \\
\text { Streptococcus, Bacillus cereus } \\
\text { Gram-negative bacteria: } \\
\text { Three strains of Escherichia coli, Salmonella } \\
\text { enteritidis, three strains of Pseudomonas } \\
\text { aeruginosa. }\end{array}$ & $\begin{array}{c}\text { DMSO }(10 \%) \\
50 \%(v / v)\end{array}$ & $\begin{array}{l}\text { Gram-positive bacteria: } \\
\text { The inhibition diameters ranged between } \\
9 \text { and } 27 \mathrm{~mm} \\
\text { Gram-negative bacteria: } \\
\text { The inhibition diameters ranged between } \\
9 \text { and } 29 \mathrm{~mm}\end{array}$ & [83] \\
\hline
\end{tabular}


Table 3. Cont.

\begin{tabular}{|c|c|c|c|c|c|c|}
\hline Effect & Country & $\begin{array}{l}\text { Type of the } \\
\text { Study }\end{array}$ & Bacteria/Fungi/Virus Strains & Extract Used & Key Results & References \\
\hline \multirow{3}{*}{ Antibacterial } & Lithuania & In vitro & $\begin{array}{c}\text { Gram-positive bacteria: } \\
\text { B. cereus 1801, methicillin-resistant } \\
\text { Staphylococcus aureus (MRSA) M87fox, E. } \\
\text { faecalis 86, S. epidermidis, S. haemolyticus, and } \\
\text { Streptococcus mutans } \\
\text { Gram-negative bacteria: } \\
\text { A. baumanniii17-380, C. freundii, E. cloacae, } \\
\text { Enterococcus faecium 103, Klebsiella pneumoniae,P. } \\
\text { multocida, P. mirabilis, Pseudomonas aeruginosa } \\
\text { 17-331, and Salmonella enterica } 24 \text { SPn06. }\end{array}$ & $\begin{array}{l}\text { One gram of bee } \\
\text { products was dissolved } \\
\text { in } 20 \mathrm{~mL} \text { of aqueous } \\
\text { ethanol }(500 \mathrm{~mL} / \mathrm{L}) \text { for } \\
6 \mathrm{~h}\end{array}$ & $\begin{array}{l}\text { The inhibition diameters ranged between } \\
\qquad 9 \text { and } 22.8 \mathrm{~mm}\end{array}$ & [73] \\
\hline & Greek & In vitro & $\begin{array}{c}\text { Gram-positive bacteria: } \\
\text { Methicillin-resistant Staphylococcus aureus } \\
\text { strain } 1552 \\
\text { Gram-negative bacteria: } \\
\text { Carbapenem-resistant Pseudomonas aeruginosa } \\
\text { strain 1773, Salmonella typhimurium, and } \\
\text { Klebsiella pneumonia }\end{array}$ & $\begin{array}{l}\text { Different amounts of bee } \\
\text { bread were extracted } \\
\text { with } 10 \mathrm{~mL} \text { of water at } \\
\text { room temperature for } 24\end{array}$ & $\begin{array}{c}\text { Gram-positive bacteria: } \\
\text { MIC values ranging between } 3.9 \mathrm{mg} / \mathrm{mL} \text { and } \\
48 \mathrm{mg} / \mathrm{mL} \\
\text { MBC values ranging between } 3.9 \mathrm{mg} / \mathrm{mL} \\
\text { and } 48 \mathrm{mg} / \mathrm{mL} \\
\text { Gram-negative bacteria: } \\
\text { MIC values ranging between } 7.8 \mathrm{mg} / \mathrm{mL} \text { and } \\
90.4 \mathrm{mg} / \mathrm{mL} \\
\text { MBC values ranging between } 9.9 \mathrm{mg} / \mathrm{mL} \\
\text { and }>93.2 \mathrm{mg} / \mathrm{mL}\end{array}$ & [84] \\
\hline & Poland & In vitro & $\begin{array}{c}\text { Gram-positive bacteria: } \\
\text { S. aureusATCC 25923, S. aureus ATCC 29213, S. } \\
\text { epidermidisATCC 12228, six MSSA } \\
\text { (methicillin-susceptible Staphylococcus aureus), } \\
\text { and three MRSA (methicillin resistant } \\
\text { Staphylococcus aureus) } \\
\text { Gram-negative bacteria: } \\
\text { P. aeruginosa ATCC } 27853 \text { and E. coli ATCC } \\
25922\end{array}$ & $\begin{array}{l}\text { BB extracted in } 70 \% \\
\text { ethanol at } v / w \text { ratio of } 7: 1 \\
\text { at ambient temperature } \\
\text { for } 2 \mathrm{~h}\end{array}$ & $\begin{array}{c}\text { Gram-positive bacteria: } \\
\text { MIC values ranging between } 2.5 \text { and } 10 \% \\
(v / w) \text {. } \\
\text { MBC values ranging between } 2.5 \text { and } 20 \% \\
\text { Gram-negative bacteria: } \\
\text { MIC values ranging between } 5 \text { and } 20 \%(v / w) \\
\text { MBC values ranging between } 10 \text { and }>20 \% \\
(v / w)\end{array}$ & [85] \\
\hline
\end{tabular}


Table 3. Cont.

\begin{tabular}{|c|c|c|c|c|c|c|}
\hline Effect & Country & $\begin{array}{l}\text { Type of the } \\
\text { Study }\end{array}$ & Bacteria/Fungi/Virus Strains & Extract Used & Key Results & References \\
\hline Antibacterial & Ukraine & In vitro & $\begin{array}{c}\text { Gram-negative bacteria: } \\
\text { Escherichia coli CCM } 3988 \text { andSalmonella } \\
\text { enterica subs. Enterica CCM } 3807 \\
\text { Gram-positive bacteria: } \\
\text { Bacillus thuringiensis CCM } 19 \text { and } \\
\text { Staphylococcus aureus subs. aureus CCM } 4223 .\end{array}$ & $\begin{array}{l}\text { BB was extracted with } \\
\text { ethanol; } \\
0.1 \mathrm{~g} \text { of BB was extracted } \\
\text { with } 20 \mathrm{~mL} \text { of ethanol } \\
\quad(80 \%) \text { for } 2 \mathrm{~h}\end{array}$ & $\begin{array}{c}\text { Gram-positive bacteria: } \\
\text { MICvalues ranging between } 12.81 \text { and } \\
27.20 \mu \mathrm{g} / \mathrm{mL} \\
\text { Gram-negative bacteria: } \\
\text { MIC values ranging between } 6.40 \text { and } \\
13.64 \mu \mathrm{g} / \mathrm{mL}\end{array}$ & {$[66]$} \\
\hline Antiviral & Greece & $\begin{array}{l}\text { Cell culture } \\
\text { method }\end{array}$ & Enterovirus D68 & $\begin{array}{l}\text { BB was dissolved in } \\
\text { Dulbecco's Modified } \\
\text { Eagle cell culture } \\
\text { medium for one hour at } \\
\text { room temperature }\end{array}$ & $\begin{array}{l}\mathrm{IC}_{50} \text { ranged between } 0.048 \text { and } 5.45 \mathrm{mg} / \mathrm{mL} \\
\mathrm{CC}_{50} \text { ranged between } 0.17 \text { and } 8.60 \mathrm{mg} / \mathrm{mL}\end{array}$ & [90] \\
\hline Antibacterial & Malaysia & In vitro & $\begin{array}{l}\text { Gram-positive bacteria: } \\
\text { L.monocytogene, S. aureus, and } \\
\text { B. cereus } \\
\text { Gram-negative bacteria: } \\
\text { E.coli, Salmonella, and } \\
\text { P. aeruginosa }\end{array}$ & $\begin{array}{l}\text { Twenty grams of BB } \\
\text { were extracted twice } \\
\text { with } 80 \mathrm{~g} \text { of } 95 \%(v / v) \\
\text { ethanol for } 12 \mathrm{~h} \text { and then } \\
\text { with } 40 \mathrm{~g} \text { of } 95 \%(v / v) \\
\text { ethanol. }\end{array}$ & $\begin{array}{c}\text { Gram-positive bacteria: } \\
\text { The inhibition diameters ranged between } 0 \\
\text { and } 284.44 \mathrm{~mm} \\
\text { Gram-negative bacteria: } \\
\text { The inhibition diameters ranged between } 0 \\
\text { and } 312.22 \mathrm{~mm}\end{array}$ & [86] \\
\hline Antibacterial & Malaysia & In vitro & $\begin{array}{l}\text { Gram-negative bacteria: } \\
\text { Klebsilla pneumonia, Escherichia coli, Shigella, and } \\
\text { Salmonella typhi }\end{array}$ & $\begin{array}{l}\text { Fifty grams of BB were } \\
\text { extracted with } 500 \mathrm{~mL} \text { of } \\
70 \% \text { ethanol and with } \\
\text { water and hot water for } \\
72 \mathrm{~h} \text { at room temperature }\end{array}$ & $\begin{array}{c}\text { Shigella (MIC: } 1.617 \mu \mathrm{g} / \mathrm{mL}) \text {, followed by } \\
\text { Salmonella typhi (MIC: } 1.813 \mu \mathrm{g} / \mathrm{mL}), \text { E. coli } \\
\text { (MIC: } 1.914 \mu \mathrm{g} / \mathrm{mL}) \text {, and Klebsilla pneumonia } \\
\text { (MIC: } 1.923 \mu \mathrm{g} / \mathrm{mL})\end{array}$ & [87] \\
\hline Antibacterial & Egypt & In vitro & $\begin{array}{c}\text { Gram-positive bacteria: } \\
\text { Staphylococcus aureus (ATCC 6538) and Bacillus } \\
\text { Subtilis(ATCC 6633) } \\
\text { Gram-negative bacteria: } \\
\text { Escherichia coli (ATCC 8739) and K. pneumonia } \\
\text { (ATCC 13883) }\end{array}$ & \multirow{2}{*}{$\begin{array}{l}\text { One hundred grams of } \\
\text { BB were soaked in } \\
200 \mathrm{~mL} \text { of ethanol } 80 \% \\
\text { for } 24 \mathrm{~h} \text { and then } \\
\text { homogenized for } \\
30 \mathrm{~min}\end{array}$} & $\begin{array}{l}\text { Gram-positive bacteria: } \\
\text { The inhibition diameters ranged between } 24 \\
\text { and } 26 \mathrm{~mm} \\
\text { Gram-negative bacteria: } \\
\text { The inhibition diameters ranged between } 12 \\
\text { and } 18 \mathrm{~mm}\end{array}$ & \multirow[t]{2}{*}[52]{} \\
\hline Antifungal & & & $\begin{array}{l}\text { Unicellular fungi Candida albicans (ATCC 10221) } \\
\text { and filamentous fungi Asp. niger }\end{array}$ & & $\begin{array}{c}\text { The inhibition diameter for Candida albicans } \\
\text { was } 15 \pm 0.73 \mathrm{~mm} \\
\text { No effect against Aspergillus niger }\end{array}$ & \\
\hline
\end{tabular}


Table 3. Cont.

\begin{tabular}{|c|c|c|c|c|c|c|}
\hline Effect & Country & $\begin{array}{l}\text { Type of the } \\
\text { Study }\end{array}$ & Bacteria/Fungi/Virus Strains & Extract Used & Key Results & References \\
\hline Antibacterial & \multirow[t]{2}{*}{ Ukraine } & \multirow[t]{2}{*}{ In vitro } & $\begin{array}{c}\text { Gram-positive bacteria: } \\
\text { Bacillus cereus CCM 2010, Clostridium } \\
\text { perfringens CCM 4435, and Staphylococcus } \\
\text { aureus subsp. aureus } \\
\text { CCM 4223 } \\
\text { Gram-negative bacteria: } \\
\text { Haemophilus influenza CCM 4456, Klebsiella } \\
\text { pneumoniae CCM 2318, and Salmonella enterica } \\
\text { subsp. enterica CCM } 3807\end{array}$ & $\begin{array}{c}\text { BB was extracted by } \\
\text { maceration using } 50 \% \\
\text { ethanol }\end{array}$ & $\begin{array}{c}\text { Gram-positive bacteria: } \\
\text { The inhibition diameters ranged between } 9 \\
\text { and } 16 \mathrm{~mm} \\
\text { Gram-negative bacteria: } \\
\text { The inhibition diameters ranged between } 1.7 \\
\text { and } 5 \mathrm{~mm}\end{array}$ & \multirow[t]{2}{*}{ [88] } \\
\hline Antifungal & & & $\begin{array}{c}\text { Candida albicans CCM 8186, Candida glabrata } \\
\text { CCM 8270, Candida tropicalis CCM 8223, } \\
\text { Aspergillus clavatus, Aspergillus flavus, } \\
\text { Aspergillus versicolor, Penicillium expansum, } \\
\text { Penicillium chrysogenum, and Penicillium } \\
\text { griseofulvum }\end{array}$ & & $\begin{array}{c}\text { Candia species: } \\
\text { The inhibition diameters ranged between } 4 \\
\text { and } 8 \mathrm{~mm} \\
\text { Fungi species: } \\
\text { The inhibition diameters ranged between } 1 \\
\text { and } 3.7 \mathrm{~mm}\end{array}$ & \\
\hline
\end{tabular}




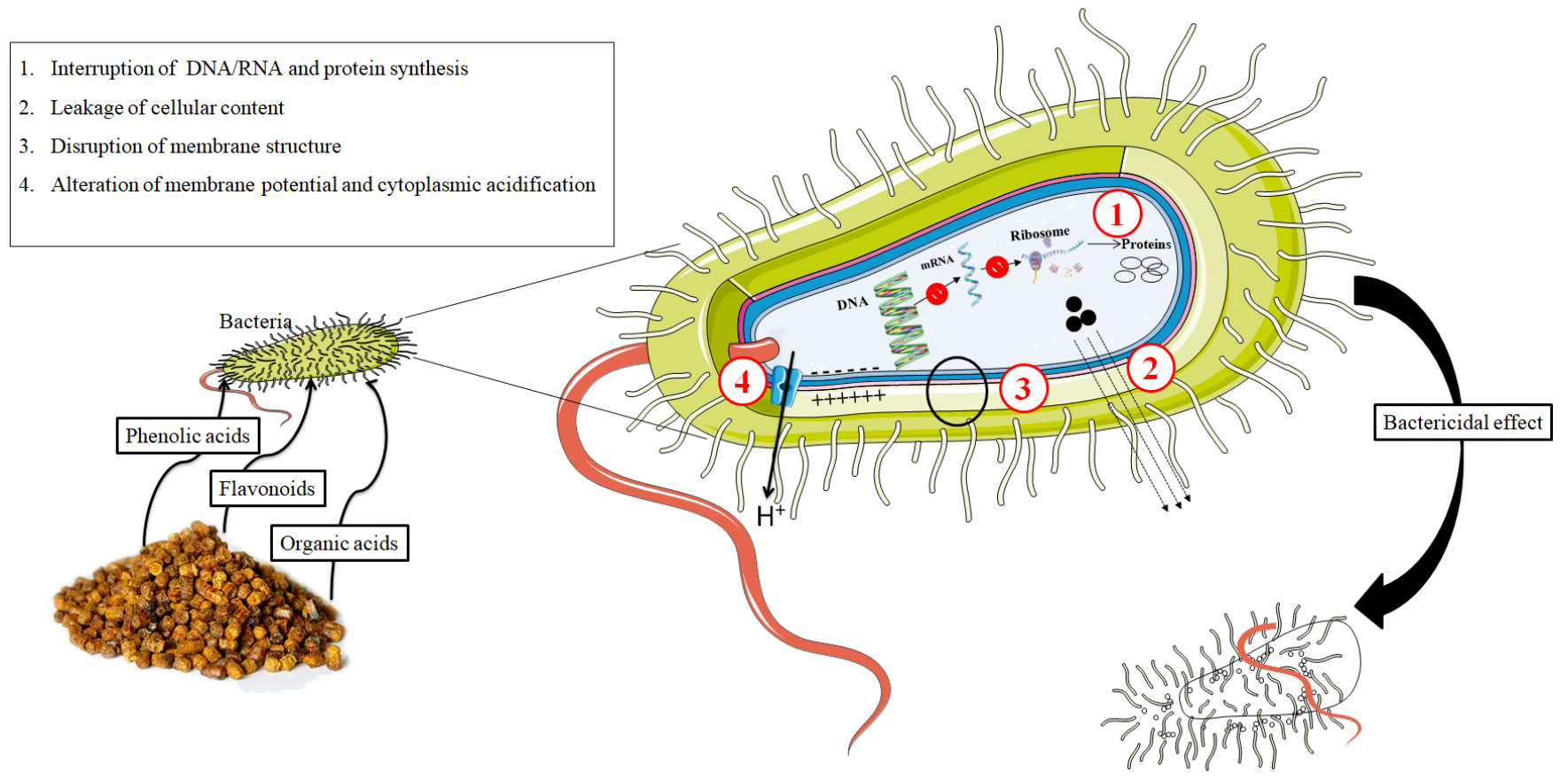

Figure 2. The possible antibacterial mechanisms of action of the bioactive molecules found in bee bread.

\section{The Pharmacological Effect of Bee Bread: In Vivo Investigations}

Moroccan bee bread was evaluated in type 1 diabetic Wistar rats; the sample was extracted using ethyl acetate and it was given orally at the dose of $100 \mathrm{mg} / \mathrm{kg}$ for 15 days. The results showed that the bee bread was effective at decreasing blood glucose levels, it protected against loss weight induced by diabetes, it possessed a hypolipidemic effect, and it protected diabetic rats against the increase in the coronary risk index, atherogenic index, and cardiovascular index [64]. In addition, the ethanolic extract of the same sample was evaluated by Bakour et al. [51] against the toxicity of titanium dioxide nanoparticles in Wistar rats. The results revealed that the bee bread reduced the elevation of aspartate aminotransferase (AST), alanine aminotransferase (ALT), lactate dehydrogenase (LDH), blood glucose, sodium, potassium, chloride, total cholesterol (TC), and low-density lipoprotein cholesterol (LDL), and it exhibited a highly protective effect against the decrease in albumin and total protein. Additionally, bee bread, at a dose of 500 and $750 \mathrm{mg} / \mathrm{kg}$, alleviated the biochemical changes induced by aluminum in rats by increasing hematocrit, hemoglobin, red blood cells, mean corpuscular hemoglobin $(\mathrm{MCH})$, mean corpuscular volume (MCV), mean corpuscular hemoglobin concentration (MCHC), urine sodium, and creatinine clearance and decreasing platelets, monocytes, lymphocytes, leukocytes, ALT, AST, C-reactive protein (CRP), and blood urea [63] (Table 4).

Malaysian bee bread was tested in two studies in high-fat diet-induced obese rats; the dose used in both investigations was $0.5 \mathrm{~g} / \mathrm{kg}$ via oral routes using distilled water. The first study conducted by Eleazu et al. [30] revealed that the administration of bee bread in obese rats decreased the percentage change in body weight, BMI index, kidney weight, MDA concentrations, inflammatory cells in kidney tissue, NFkB, TNF- $\alpha$, interleukin-L-beta, and Bax, while it increased the levels of SOD, GPx, GST, and TAA and reduced the Bowman's capsule space in the urinary chambers of the kidneys. In the second study conducted by Othman et al. [106], the administration of bee bread in obese male Sprague-Dawley rats improved their lipid profile, aortic inflammatory markers, and their impaired vasorelaxation activity, and showed its ability to enhance nitric oxide release and promote endothelial nitric oxide synthase (eNOS) and cyclic guanosine monophosphate (cGMP) immunoexpression. The same protocol forhigh-fat diet-induced obese rats was used by Suleiman et al. [107] to examine the protective effect of bee bread at a dose of $0.5 \mathrm{~g} / \mathrm{kg}$ once daily for 12 weeks on 
testicular oxidative stress, inflammation, apoptosis, and lactate transport in the testes of obese rats (Table 4).

Several studies have examined the ability of bee bread to lower blood pressure. These studies have evaluated the effects of the oral administration of bee bread extract on vascular inflammation and impaired vasorelaxation in vivo using an obesity-induced vascular damage rat model $[30,108]$. The authors reported that bee bread improved the impaired vasorelaxation activity by enhancing the release of nitric oxidase, endothelial nitric oxide (sNOS), and cyclic guanosine monophosphate immunoexpression, which provide vascular protection. In addition, it has been proven that bee bread boosts the aortic antioxidant activities impaired in high-fat diet-induced obese rats by ameliorating aortic proinflammatory markers (tumor necrosis factor- $\alpha$ and nuclear factor $-\kappa \beta$ ) and preventing aortic structural damage perturbation in the vasorelaxation response to acetylcholine [30]. The phytochemical analysis of bee bread reveals its diverse phytochemical compounds with high antioxidant potential, including ferulic acid, caffeic acid, kaempferol, apigenin, and isorhamnetin. These bioactive molecules have proven their ability to act as antiatherogenic agents against the perturbations induced by a high-fat diet [108].

In the same context, Martiniakova et al. [109] reported that the oral administration of monofloral bee bread extract (Brassica napus L.) significantly lowered blood glucose levels, prevented lipid abnormalities, and impaired the bone morphology of Zucker diabetic fatty rats. In addition, Haščík et al. [110] showed the effect of dietary bee bread powder on the chemical composition of Japanese quails meat. In the breast muscle of quails, the bee bread decreased the water content, increased the crude protein content, and decreased fat and cholesterol, while in the thigh muscle of quails, the dietary bee bread increased the water content, fat, and cholesterol.

In Turkey, the effect of bee bread on leptin and ghrelin expression in obese rats was studied by Doğanyiğit et al. [111] in Sprague-Dawley adult female rats using two doses via oral administration; the results showed that bee bread decreased ghrelin immunoreactivity, increased leptin immunoreactivity, decreased the apoptotic cell numbers in the hypothalamus, and decreased MDA levels. In addition, it was shown that bee bread from Slovakia reduced femoral bone structure and improved glucose and lipid metabolism in Zucker diabetic fatty rats [112]; bee bread from China has also been shown to have a capacity for the regulation of lipid metabolism [113]. 
Table 4. Pharmacological properties of bee bread in vivo.

\begin{tabular}{|c|c|c|c|c|c|c|c|c|c|c|}
\hline Country & $\begin{array}{c}\text { Functional } \\
\text { Effect }\end{array}$ & Protocol Used & $\begin{array}{c}\text { Palynological } \\
\text { Analysis of Bee } \\
\text { Bread (BB) }\end{array}$ & $\begin{array}{l}\text { The Majority of } \\
\text { Compounds } \\
\text { Identified }\end{array}$ & $\begin{array}{l}\text { Extraction } \\
\text { Used }\end{array}$ & $\begin{array}{l}\text { Concentration/ } \\
\text { Treatment } \\
\text { Duration }\end{array}$ & $\begin{array}{l}\text { Administration } \\
\text { Routes }\end{array}$ & $\begin{array}{l}\text { Model } \\
\text { Used }\end{array}$ & Results Obtained & References \\
\hline Morocco & $\begin{array}{c}\text { Hypoglycemic, } \\
\text { hypolipidemic, and } \\
\text { hepatoprotective } \\
\text { effects }\end{array}$ & $\begin{array}{l}\text { Streptozotocin- } \\
\text { induced diabetic } \\
\text { rats }\end{array}$ & $\begin{array}{c}\text { Bupleurum spinosum, } \\
\text { Anethum graveolens, } \\
\text { Calendula officinalis, } \\
\text { Anacyclus, Quercus } \\
\text { ilex, Eucalyptus, } \\
\text { Punica granatum, } \\
\text { and Acacia }\end{array}$ & $\begin{array}{l}\text { Isorhamnetin-O- } \\
\text { hexosyl-O- } \\
\text { rutinoside was the } \\
\text { major phenolic } \\
\text { compound } \\
\text { present, in } \\
\text { addition to } \\
\text { tocopherols }\end{array}$ & $\begin{array}{l}\text { Ethyl } \\
\text { acetate } \\
\text { extract }\end{array}$ & $\begin{array}{l}100 \mathrm{mg} / \mathrm{kg} \\
\text { For } 15 \text { days }\end{array}$ & Oral & Wistar rats & $\begin{array}{c}\downarrow \text { Blood glucose levels } \\
\text { Protect against weightloss } \\
\downarrow \text { TC, } \uparrow \text { HDL, } \downarrow \text { TG, } \downarrow \text { LDL }, \downarrow \\
\text { VLDL } \\
\text { Coronary risk index } \\
\downarrow \text { Atherogenic index } \\
\downarrow \text { Cardiovascular index }\end{array}$ & [64] \\
\hline Morocco & $\begin{array}{l}\text { Protective effects } \\
\text { against anemia, } \\
\text { inflammation, and } \\
\text { hepato-renal toxicity }\end{array}$ & $\begin{array}{l}\text { Toxicity of } \\
\text { aluminum }\end{array}$ & $\begin{array}{c}\text { One sample } \\
\text { (not determined) }\end{array}$ & $\begin{array}{c}\text { Polyphenol } \\
\text { content: } 14.88 \pm \\
0.98 \mathrm{mg} \text { GAE } / \mathrm{g} \\
\text { Flavonoid content: } \\
1.67 \pm 0.12 \mathrm{mg} \\
\mathrm{QE} / \mathrm{g}\end{array}$ & $\begin{array}{l}\text { Maceration } \\
\text { for one } \\
\text { week in } 70 \% \\
\text { ethanol } \\
\text { under } \\
\text { agitation }\end{array}$ & $\begin{array}{c}500 \text { and } 750 \\
\mathrm{mg} / \mathrm{kg}\end{array}$ & Oral & $\begin{array}{l}\text { Male Wistar } \\
\text { rats }\end{array}$ & $\begin{array}{c}\uparrow \text { Hematocrit, hemoglobin, } \\
\text { red blood cells, MCH, MCV, } \\
\text { and MCHC } \\
\downarrow \text { Platelets, monocytes, } \\
\text { lymphocytes, and leukocytes. } \\
\downarrow \text { ALT, AST, and CRP } \\
\downarrow \text { Blood urea } \\
\uparrow \text { Urine sodium and } \\
\text { creatinine clearance }\end{array}$ & [63] \\
\hline Morocco & $\begin{array}{l}\text { Protective effects } \\
\text { against the toxicity } \\
\text { induced by titanium } \\
\text { dioxide in } \\
\text { biochemical } \\
\text { parameters of the } \\
\text { brain, liver, and } \\
\text { kidney tissues }\end{array}$ & $\begin{array}{c}\text { Titanium } \\
\text { dioxide } \\
\text { nanoparticles } \\
\text { induced toxicity } \\
\text { in rats }\end{array}$ & $\begin{array}{c}\text { Bupleurum spinosum, } \\
\text { Anethum graveolens, } \\
\text { Calendula officinalis, } \\
\text { Anacyclus, Quercus } \\
\text { ilex, Eucalyptus, } \\
\text { Punica granatum, and } \\
\text { Acacia }\end{array}$ & $\begin{array}{l}\text { Isorhamnetin-O- } \\
\text { hexosyl-O- } \\
\text { rutinoside was the } \\
\text { major phenolic } \\
\text { compound } \\
\text { present, in } \\
\text { addition to } \\
\text { tocopherols }\end{array}$ & $\begin{array}{c}\text { Ethanolic } \\
\text { extract }\end{array}$ & $\begin{array}{l}100 \mathrm{mg} / \mathrm{kg} \\
\text { For } 30 \text { days }\end{array}$ & Oral & Wistar rats & $\begin{array}{c}\downarrow \text { AST, } \downarrow \text { ALT, } \downarrow \text { LDH } \\
\downarrow \text { TC, } \uparrow \text { HDL, } \downarrow \text { LDL } \\
\downarrow \text { Blood glucose levels } \\
\downarrow \text { Urea, } \uparrow \text { Albumin, } \uparrow \text { Total } \\
\text { protein } \\
\downarrow \text { Sodium, } \downarrow \text { potassium, } \downarrow \\
\text { chloride } \\
\text { Protection against } \\
\text { histopathological changes in } \\
\text { the brain, kidneys, and liver }\end{array}$ & [51] \\
\hline Slovakia & $\begin{array}{l}\text { Alleviates lipid } \\
\text { abnormalities and } \\
\text { impaired bone } \\
\text { morphology in } \\
\text { obese Zucker } \\
\text { diabetic rats }\end{array}$ & $\begin{array}{l}\text { Obese Zucker } \\
\text { diabetic rats }\end{array}$ & $\begin{array}{c}\text { Monofloral } \\
\text { (Brassica napus L.) }\end{array}$ & $\begin{array}{c}\text { Vitamin A, } \\
\text { vitamin E } \\
\text { vitamin } C \text {, vitamin } \\
\text { B2, vitamin B3, } \\
\text { and } \\
\text { Beta carotene }\end{array}$ & $\begin{array}{l}\text { Mixed with } \\
\text { distilled } \\
\text { water }\end{array}$ & $\begin{array}{c}500 \text { and } 700 \\
\mathrm{mg} / \mathrm{kg}\end{array}$ & Oral & $\begin{array}{c}\text { Zucker } \\
\text { diabetic } \\
\text { Fatty rats }\end{array}$ & $\begin{array}{c}\downarrow \text { Blood glucose level } \\
\downarrow \text { TC, } \downarrow \text { triglycerides } \\
\uparrow \text { the relative volume of } \\
\text { trabecular bone } \\
\uparrow \text { trabecular thickness, } \\
\text { enhanced density of } \\
\text { secondary osteons, } \\
\text { accelerated periosteal bone } \\
\text { apposition, and improved } \\
\text { blood flow }\end{array}$ & [109] \\
\hline
\end{tabular}


Table 4. Cont.

\begin{tabular}{|c|c|c|c|c|c|c|c|c|c|c|}
\hline Country & $\begin{array}{c}\text { Functional } \\
\text { Effect }\end{array}$ & Protocol Used & $\begin{array}{l}\text { Palynological } \\
\text { Analysis of Bee } \\
\text { Bread (BB) }\end{array}$ & $\begin{array}{l}\text { The Majority of } \\
\text { Compounds } \\
\text { Identified }\end{array}$ & $\begin{array}{l}\text { Extraction } \\
\text { Used }\end{array}$ & $\begin{array}{l}\text { Concentration/ } \\
\text { Treatment } \\
\text { Duration }\end{array}$ & $\begin{array}{l}\text { Administration } \\
\text { Routes }\end{array}$ & $\begin{array}{l}\text { Model } \\
\text { Used }\end{array}$ & Results Obtained & References \\
\hline Malaysia & $\begin{array}{c}\text { Protective effect } \\
\text { against testicular } \\
\text { oxidative stress, } \\
\text { inflammation, } \\
\text { apoptosis, and } \\
\text { lactate transport in } \\
\text { the testes of obese } \\
\text { rats }\end{array}$ & $\begin{array}{l}\text { High-fat diet } \\
\text { (HFD) }\end{array}$ & $\begin{array}{l}\text { One sample (not } \\
\text { determined) }\end{array}$ & $\begin{array}{c}\text { Riboflavin, } \\
\text { thiamine, vitamin } \\
\text { A, vitamin E, Fe, } \\
\mathrm{Cu}, \mathrm{Zn} \text {, apigenin, } \\
\text { caffeic acid, ferulic } \\
\text { acid, isorhamnetin, } \\
\text { andkaempferol }\end{array}$ & $\begin{array}{l}\text { Blended } \\
\text { and used as } \\
\text { a fine } \\
\text { powder }\end{array}$ & $\begin{array}{c}0.5 \mathrm{~g} / \mathrm{kg} / \text { day) } \\
\text { once daily for } 12 \\
\text { weeks. }\end{array}$ & Oral & $\begin{array}{c}\text { Male } \\
\text { Sprague- } \\
\text { Dawley } \\
\text { rats }\end{array}$ & 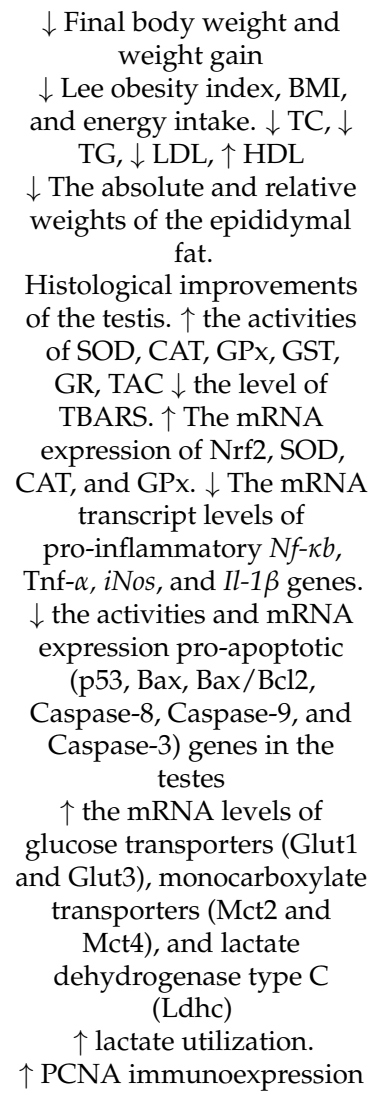 & [107] \\
\hline
\end{tabular}


Table 4. Cont.

\begin{tabular}{|c|c|c|c|c|c|c|c|c|c|c|}
\hline Country & $\begin{array}{c}\text { Functional } \\
\text { Effect }\end{array}$ & Protocol Used & $\begin{array}{l}\text { Palynological } \\
\text { Analysis of Bee } \\
\text { Bread (BB) }\end{array}$ & $\begin{array}{l}\text { The Majority of } \\
\text { Compounds } \\
\text { Identified }\end{array}$ & $\begin{array}{l}\text { Extraction } \\
\text { Used }\end{array}$ & $\begin{array}{l}\text { Concentration/ } \\
\text { Treatment } \\
\text { Duration }\end{array}$ & $\begin{array}{l}\text { Administration } \\
\text { Routes }\end{array}$ & $\begin{array}{l}\text { Model } \\
\text { Used }\end{array}$ & Results Obtained & References \\
\hline Turkey & $\begin{array}{l}\text { The effects of bee } \\
\text { bread on leptin and } \\
\text { ghrelin expression in } \\
\text { obese rats }\end{array}$ & $\begin{array}{c}\text { Female rats } \\
\text { became obese } \\
\text { with a high-fat } \\
\text { diet }\end{array}$ & $\begin{array}{c}\text { One sample } \\
\text { (not determined) }\end{array}$ & $\begin{array}{c}\text { Protein: } \\
13.56 \mathrm{~g} / 100 \mathrm{~g} \\
\text { Carbohydrate: } \\
30.60 \mathrm{~g} / 100 \mathrm{~g} \\
\text { Dietary fiber: } \\
18.18 \mathrm{~g} / 100 \mathrm{~g} \\
\text { Fat: } 21.69 \mathrm{~g} / 100 \mathrm{~g}\end{array}$ & $\begin{array}{l}\text { Distilled } \\
\text { water }\end{array}$ & $\begin{array}{l}\text { Concentration } 1 \text { : } \\
100 \mathrm{mg} / \mathrm{kg} / \text { day } \\
\text { Concentration2: } \\
200 \mathrm{mg} / \mathrm{kg} / \text { day }\end{array}$ & Oral & $\begin{array}{l}\text { Sprague- } \\
\text { Dawley } \\
\text { adult female } \\
\text { rats }\end{array}$ & $\begin{array}{c}\downarrow \text { Ghrelin immunoreactivity } \\
\text { in obese rats that received BB } \\
\text { (100 mg/kg/day and } \\
200 \mathrm{mg} / \mathrm{kg} / \text { day). } \uparrow \text { Leptin } \\
\text { immunoreactivity in obese } \\
\text { rats that received BB } \\
(100 \mathrm{mg} / \mathrm{kg} / \text { day and } \\
200 \mathrm{mg} / \mathrm{kg} / \text { day). } \\
\downarrow \text { Apoptotic cell numbers in } \\
\text { hypothalamus tissue } \\
\text { in obese rats that received BB } \\
\text { (100 } \mathrm{mg} / \mathrm{kg} / \text { day and } \\
200 \mathrm{mg} / \mathrm{kg} / \text { day) } \\
\uparrow \mathrm{SOD} \text { activity in obese rats } \\
\text { that received BB } \\
\text { (200 mg/kg/day). } \downarrow \text { Ghrelin } \\
\text { amounts in obese rats that } \\
\text { received BB } \\
\text { (200 } \mathrm{mg} / \mathrm{kg} / \text { day). } \uparrow \text { Leptin } \\
\text { amounts in obese rats that } \\
\text { received BB } \\
\text { (200 } \mathrm{mg} / \mathrm{kg} / \text { day). } \downarrow \text { MDA } \\
\text { levels in obese rats that } \\
\text { received } \\
\text { BB (200 mg/kg/day) }\end{array}$ & [112] \\
\hline Slovakia & $\begin{array}{l}\text { The effects of dietary } \\
\text { bee bread powder } \\
\text { on the chemical } \\
\text { composition of quail } \\
\text { meat. }\end{array}$ & $\begin{array}{l}\text { Dietary supple- } \\
\text { mentation of bee } \\
\text { bread powder in } \\
\text { quails }\end{array}$ & $\begin{array}{c}\text { One sample } \\
\text { (not determined) }\end{array}$ & (not determined) & $\begin{array}{l}\text { Bee bread } \\
\text { powder }\end{array}$ & $\begin{array}{l}2 \mathrm{~g} \text { or } 4 \mathrm{~g} \text { or } 6 \mathrm{~g} \\
\text { per } 1 \mathrm{~kg} \text { of feed } \\
\text { mixture }\end{array}$ & Oral & $\begin{array}{l}\text { Japanese } \\
\text { quails }\end{array}$ & $\begin{array}{c}\text { The effect of BB } \\
\text { supplementation on the } \\
\text { chemical composition of } \\
\text { breast muscle in quails: } \\
\downarrow \text { Water content } \\
\uparrow \text { Crude protein } \\
\downarrow \text { Fat } \\
\downarrow \text { Cholesterol } \\
\text { The effect of BB } \\
\text { supplementation on the } \\
\text { chemical composition of } \\
\text { thigh muscle in quails } \\
\uparrow \text { Water content } \\
\uparrow \text { Fat } \\
\uparrow \text { cholesterol }\end{array}$ & [110] \\
\hline
\end{tabular}


Table 4. Cont.

\begin{tabular}{|c|c|c|c|c|c|c|c|c|c|c|}
\hline Country & $\begin{array}{c}\text { Functional } \\
\text { Effect }\end{array}$ & Protocol Used & $\begin{array}{c}\text { Palynological } \\
\text { Analysis of Bee } \\
\text { Bread (BB) }\end{array}$ & $\begin{array}{l}\text { The Majority of } \\
\text { Compounds } \\
\text { Identified }\end{array}$ & $\begin{array}{l}\text { Extraction } \\
\text { Used }\end{array}$ & $\begin{array}{l}\text { Concentration/ } \\
\text { Treatment } \\
\text { Duration }\end{array}$ & $\begin{array}{l}\text { Administration } \\
\text { Routes }\end{array}$ & $\begin{array}{l}\text { Model } \\
\text { Used }\end{array}$ & Results Obtained & References \\
\hline China & $\begin{array}{l}\text { Regulation of lipid } \\
\text { metabolism }\end{array}$ & SPF rats & Not mentioned & - & & $\begin{array}{c}80,400, \text { and } 800 \\
\mathrm{mg} / \mathrm{kg} \text { during } \\
20 \text { days }\end{array}$ & Oral & Rats & $\begin{array}{c}\downarrow \text { Fatty acid Synthase } \\
\downarrow \text { Acetyl CoA carboxylase } \downarrow \\
\text { lipoprotein lipase } \downarrow \text { Total } \\
\text { cholesterol level, } \downarrow \\
\text { triglycerides, } \uparrow \text { HDL, } \downarrow \text { LDL }\end{array}$ & [111] \\
\hline Malaysia & $\begin{array}{c}\text { Bee bread attenuates } \\
\text { high-fat diet (HFD) } \\
\text { induced renal } \\
\text { pathology in obese } \\
\text { rats via } \\
\text { The modulation of } \\
\text { oxidative stress, } \\
\text { down regulation of } \\
\text { NF-kB mediated } \\
\text { inflammation, } \\
\text { and Bax signaling }\end{array}$ & High-fat diet & $\begin{array}{c}\text { One sample } \\
\text { (not determined) }\end{array}$ & $\begin{array}{c}\text { Protein: } \\
3.37 \pm 0.30 \% \\
\text { Lipid: } \\
4.32 \pm 0.17 \% \\
\text { Carbohydrate: } \\
82.45 \pm 0.36 \% \\
\text { Iron:0.02 ppm } \\
\text { Copper: } 0.01 \mathrm{ppm} \\
\text { Zinc: } 0.002 \mathrm{ppm} \\
\text { Vitamin A: } 146.8 \\
\pm 6.21(\mathrm{mg} / 100 \mathrm{~g}) \\
\text { Vitamin } \mathrm{E}: \\
46.27 \pm 0.67 \\
\text { (mg/100 g) } \\
\text { Thiamine: } 6.20 \pm \\
0.06 \text { (mg/100 g) } \\
\text { Riboflavin: } \\
0.50 \pm 0.00 \\
\text { (mg/100 g) }\end{array}$ & $\begin{array}{l}\text { Distilled } \\
\text { water }\end{array}$ & $0.5 \mathrm{~g} / \mathrm{kg}$ & Oral & $\begin{array}{l}\text { Male } \\
\text { Sprague- } \\
\text { Dawley } \\
\text { rats }\end{array}$ & $\begin{array}{c}\downarrow \% \text { change in body weight, } \\
\text { BMI index in rats that } \\
\text { received HFD treated or } \\
\text { protected with BB. } \downarrow \text { Kidney } \\
\text { weight in rats that received } \\
\text { HFD treated or protected } \\
\text { with BB. } \uparrow \text { SOD, GPx, GST, } \\
\text { TAA in rats that received } \\
\text { HFD treated or protected } \\
\text { with BB } \\
\downarrow \text { MDA concentrations in } \\
\text { rats that received HFD } \\
\text { treated or protected with BB } \\
\downarrow \text { Inflammatory cells in } \\
\text { kidney tissues of HFD } \\
\text { groups treated or protected } \\
\text { with BB. } \downarrow \text { Bowman's } \\
\text { capsule space in the urinary } \\
\text { chamber of kidneys of HFD } \\
\text { groups treated or protected } \\
\text { with BB. } \downarrow \text { NFkB, TNF- } \alpha, \\
\text { interleukin-1-beta, and Bax } \\
\text { in rats that received HFD } \\
\text { treated or protected with BB }\end{array}$ & [30] \\
\hline
\end{tabular}


Table 4. Cont.

\begin{tabular}{|c|c|c|c|c|c|c|c|c|c|c|}
\hline Country & $\begin{array}{c}\text { Functional } \\
\text { Effect }\end{array}$ & Protocol Used & $\begin{array}{l}\text { Palynological } \\
\text { Analysis of Bee } \\
\text { Bread (BB) }\end{array}$ & $\begin{array}{l}\text { The Majority of } \\
\text { Compounds } \\
\text { Identified }\end{array}$ & $\begin{array}{l}\text { Extraction } \\
\text { Used }\end{array}$ & $\begin{array}{l}\text { Concentration/ } \\
\text { Treatment } \\
\text { Duration }\end{array}$ & $\begin{array}{l}\text { Administration } \\
\text { Routes }\end{array}$ & $\begin{array}{l}\text { Model } \\
\text { Used }\end{array}$ & Results Obtained & References \\
\hline Malaysia & $\begin{array}{l}\text { Bee bread } \\
\text { ameliorates the } \\
\text { impaired } \\
\text { vasorelaxation } \\
\text { response to ACh by } \\
\text { improving the } \\
\text { eNOS/NO/cGMP- } \\
\text { signaling pathway } \\
\text { in obese rats }\end{array}$ & High-fat diet & $\begin{array}{c}\text { One sample } \\
\text { (not determined) }\end{array}$ & $\begin{array}{c}\text { Potassium } \\
\text { (7323.04 mg } / \mathrm{kg}), \\
\text { magnesium } \\
(1530.87 \mathrm{mg} / \mathrm{kg}), \\
\text { calcium } \\
(1108.48 \mathrm{mg} / \mathrm{kg}), \\
\text { sodium } \\
(252.73 \mathrm{mg} / \mathrm{kg}) \\
\text { iron } \\
(56.58 \mathrm{mg} / \mathrm{kg}) \\
\text { zinc } \\
(42.36 \mathrm{mg} / \mathrm{kg}) \\
\text { copper } \\
(11.05 \mathrm{mg} / \mathrm{kg}) \\
\text { and } \\
\text { selenium } \\
(0.13 \mathrm{mg} / \mathrm{kg})\end{array}$ & $\begin{array}{l}\text { Distilled } \\
\text { water }\end{array}$ & $0.5 \mathrm{~g} / \mathrm{kg}$ & Oral & $\begin{array}{c}\text { Male } \\
\text { Sprague- } \\
\text { Dawley } \\
\text { rats }\end{array}$ & $\begin{array}{l}\text { BB improves the lipid profile, } \\
\text { aortic inflammatory markers, } \\
\text { and impaired vasorelaxation } \\
\text { activity. } \\
\text { BB enhances nitric oxide } \\
\text { release, promotes endothelial } \\
\text { nitric oxide synthase (eNOS) } \\
\text { and cyclic guanosine } \\
\text { monophosphate (cGMP) } \\
\text { immunoexpression. }\end{array}$ & [106] \\
\hline Slovakia & $\begin{array}{l}\text { Reduced femoral } \\
\text { bone structure and } \\
\text { improved glucose } \\
\text { and lipid } \\
\text { metabolism in } \\
\text { Zucker diabetic fatty } \\
\text { (ZDF) rats }\end{array}$ & $\begin{array}{c}\text { Obese Zucker } \\
\text { diabetic rats }\end{array}$ & Not mentioned & - & $\begin{array}{c}\text { The sample } \\
\text { was crushed } \\
\text { and mixed } \\
\text { with } \\
\text { distilled } \\
\text { water }\end{array}$ & $500 \mathrm{mg} / \mathrm{kg}$ & Oral & $\begin{array}{l}\text { Diabetic } \\
\text { fatty rats }\end{array}$ & $\begin{array}{c}\downarrow \text { Fasting blood glucose level } \\
\downarrow \text { Total cholesterol level, } \downarrow \\
\text { triglycerides, protection } \\
\text { against body weight loss, } \downarrow \\
\text { ALP activity, } \downarrow \text { cortical bone } \\
\text { surface, relative bone } \\
\text { volume, } \uparrow \text { trabecular bone, } \uparrow \\
\text { trabecular thickness, and } \\
\text { trabecular } \\
\text { bone surface }\end{array}$ & [113] \\
\hline
\end{tabular}

$\uparrow:$ Increase; $\downarrow$ Decrease. 


\section{The Use of Bee Bread in Clinical Studies}

\subsection{Hepatoprotective Effect}

Bee bread was tested by Čeksterytè et al. [114] in patients with chronic hepatitis. The most important clinically relevant finding was a significant improvement in blood parameters, including erythrocyte count, hemoglobin, leukocytes, C-reactive protein (CRP), blood sugar, aspartate aminotransferase (AST), alanine aminotransferase (ALT), and bilirubin.

\subsection{Anti-Atherogenic Dyslipidemic Effect}

Kas'ianenko et al. [115] evaluated the effectiveness of treating patients with atherogenic dyslipidemia with a mixture of honey, pollen, and bee bread. The parameters of atherogenic dyslipidemia were examined in 157 patients (64 men and 93 women) aged 39 to 72 years. These patients were divided into four groups: (1) treated with a lipid-lowering diet only; (2) treated with a lipid-lowering diet and honey or pollen; (3) treated with bee bread only; and (4) treated with honey and pollen. The results obtained showed that a significant lipid-lowering effect was recorded in the patients taking honey in combination with pollen (total cholesterol decreased by $18.3 \%$ and LDL-C decreased by $23.9 \%$ ) and bee bread (total cholesterol decreased by $15.7 \%$ and LDL-C decreased by $20.5 \%$ ).

\subsection{Strengthening Visual Acuity}

Jarušaitienè et al. [116] studied refractive status, visual acuity, and ocular prophylaxis in 34 children (aged 6 to 17) with thyroid disease before and after taking bee bread. The results of this study showed an increase in visual acuity in the subjects who used bee bread.

\subsection{Ergogenic Effect and Improvement of Athletic Performance}

Chen et al. [117] examined the effects of bee bread supplementation during recovery on athletic performance. Twelve athletes were chosen for the study. During the experimental trials, the participants ran on a treadmill for $90 \mathrm{~min}$ and then rested for four hours. During this recovery period, the participants consumed $30 \mathrm{~g} / \mathrm{h}$ of bee bread or a placebo. Heart rate and tympanic temperature were measured at 20-min intervals during this period. Blood samples were taken to determine plasma glucose, hemoglobin, and hematocrit. Participants then performed a 20-min trial on a treadmill. The distance traveled in the bee bread trial was significantly longer than the placebo trial $(3.45 \pm 0.4 \mathrm{~km}$ vs. $3.24 \pm 0.4 \mathrm{~km}$, respectively). The plasma glucose levels in the bee bread trial were significantly higher compared to those in the placebo trial during recovery. These results showed that the supplementation of bee bread during the recovery phase appears to provide improved athletic performance in athletes.

In a second study conducted by Fadzel et al. [118], bee bread supplementation was tested on the running performance of athletes. This time, the athletes were given $20 \mathrm{~g}$ of bee bread or a placebo every day for 8 weeks. After the first experimental run, there was a 4-week washout period. Then, they continued with the supplementation for 8 weeks before the second experimental trial. During the experimental trials, the participants ran at $60 \% \mathrm{VO}_{2}$ max for $90 \mathrm{~min}$, immediately followed by a 20 -min trial. Heart rate, oxygen uptake, ear temperature, perceived exertion rate, ambient temperature, and relative humidity were recorded during the tests. Blood tests were performed to determine the levels of plasma glucose and free fatty acids. The results of the study showed that there was no significant difference between the bee bread test and the placebo test for heart rate, oxygen uptake, tympanic temperature, the rate of perceived exertion, and plasma glucose levels. However, the distance traveled in the bee bread trial was significantly greater than that in the placebo trial ( $3.41 \pm 0.2 \mathrm{~km}$ vs. $3.28 \pm 0.2 \mathrm{~km}$, respectively). In addition, the free fatty acid plasma levels in the bee bread trial were significantly higher than in the placebo trial. This allowed the researchers to conclude that supplementation with bee bread appeared to improve the running performance of athletes [118]. 


\section{Bee Bread Adulteration}

Hive products, namely honey and bee pollen, have long since been considered as a functional food for their broad-based composition and wide range of biological activities. Recently, the use of these products has increased all over the world because of public awareness of their nutritional and therapeutic properties, which could lead to a substantial economic-motivated adulteration.

Bee bread is a bee-derived product with an extended range of bioactive compounds; however, it is still not well-known and has a scarce production in the apiaries because of the difficult harvesting methods and the beekeepers' conviction that bee bread reserves in the hives should not be reduced to preserve the colonies' development [119]. The growing consumer attention regarding the health benefits of bee bread has increased its demand in the market compared with its production, which sets the stage for its adulteration and becomes an issue of concern for all bee product producers. However, the international scientific community has just started to define the regulation and quality criteria of bee products. Thus far, there are no acknowledged standards for bee bread, which makes it difficult to detect its falsification [120,121].

Based on the composition previously discussed in the present work, the detection of fraudulent bee bread manipulations requires the combination of multiple techniques mainly based on the composition of pollen in bee bread [122], including the identification of the floral origin of the bee pollen (starter matrices to the bee bread production) by a palynological survey [123] and the spectroscopic determination of the chemical composition of the bee bread, notably its vitamins (vitamin $C$, vitamin $E$, and $\beta$-carotene), amino acids, and fatty acids (taking into consideration the relationship between the botanical origin and chemical composition of bee pollen) [124,125]. Recently, advanced foodomics technologies have been used to characterize food products and have been applied to bee bread and other bee products to assess authenticity, safety, and quality issues and to determine the bioactive compounds present and their biological activities. In their review article, Kafantaris et al. [126] summarized the different methods used for the study of bee bread, including genomics as an alternative for the palynologic/microscopic determination of the botanical origin using the metabarcoding of DNA isolated from bee pollen and bee bread samples. The proteomics and metabolomics technologies can be performed using GC-MS, HPLC-DAD, SDS-PAGE, 2D-electrophoresis, and MALDI-MS methods for the identification of proteins, enzymes, fatty acids, the phenolic profile, and carotenoid composition. Additionally, metagenomics can beapplied to investigate the microbial community of bee bread, especially lactobacillus bacteria [126].

On this basis, we can conclude that the determination of the botanical origin of bee pollen, its chemical and enzymatic composition, and the characterization of its microbiome and biological properties are necessary for the authenticity, traceability, and safety of bee bread.

\section{Conclusions}

In conclusion, bee bread is a functional food produced by the fermentation of bee pollen and honey in the honeycombs of the hives. It contains a wide range of components, such as sugars, polyphenols, vitamins, and free amino acids. Bee bread is characterized by considerable pharmacological properties, proven in vitro and in vivo. Thus, it can be stated that bee bread offers a wide field for the exploitation of its benefits in the food and pharmaceutical industries.

Author Contributions: Conceptualization, M.B. and B.L.; methodology, M.B., D.O. and H.L.; data curation, H.M. and I.E.-S.; writing — original draft preparation, M.B.; writing—review and editing, D.O., A.E.G. and H.L.; supervision, B.L. All authors have read and agreed to the published version of the manuscript.

Funding: This research received no external funding.

Data Availability Statement: Data are available upon request. 
Acknowledgments: Special thanks to Badiaa lyoussi, recently awarded at Sidi Mohamed Ben Abdellah University, for her long career in the Apitherapy and Natural Products Research. Open access funding provided by University of Helsinki.

Conflicts of Interest: The authors declare no conflict of interest.

\section{References}

1. Premratanachai, P.; Chanchao, C. Review of the Anticancer Activities of Bee Products. Asian Pac. J. Trop. Biomed. 2014, 4, 337-344 [CrossRef]

2. Kolayli, S.; Keskin, M. Chapter 7-Natural bee products and their apitherapeutic applications. In Studies in Natural Products Chemistry; Elsevier: Amsterdam, The Netherlands, 2020; Volume 66, pp. 175-196. ISBN 1572-5995.

3. Urcan, A.; Mărghitaș, L.A.; Dezmirean, D.S.; Bobiș, O.; Bonta, V.; Mureșan, C.I.; Mărgăoan, R. Chemical composition and biological activities of beebread-review. In Bulletin of the University of Agricultural Sciences E Veterinary Medicine Cluj-Napoca; Animal Science \& Biotechnologies; Academic Press: Cambridge, MA, USA, 2017; Volume 74.

4. Dolezal, A.G.; Toth, A.L. Feedbacks between Nutrition and Disease in Honey Bee Health. Curr. Opin. Insect Sci. 2018, 26, 114-119. [CrossRef]

5. Vaudo, A.D.; Tooker, J.F.; Grozinger, C.M.; Patch, H.M. Bee Nutrition and Floral Resource Restoration. Curr. Opin. Insect Sci. 2015, 10, 133-141. [CrossRef] [PubMed]

6. Mohammad, S.M.; Mahmud-Ab-Rashid, N.-K.; Zawawi, N. Stingless Bee-Collected Pollen (Bee Bread): Chemical and Microbiology Properties and Health Benefits. Molecules 2021, 26, 957. [CrossRef]

7. Aylanc, V.; Falcão, S.I.; Ertosun, S.; Vilas-Boas, M. From the Hive to the Table: Nutrition Value, Digestibility and Bioavailability of the Dietary Phytochemicals Present in the Bee Pollen and Bee Bread. Trends Food Sci. Technol. 2021, 109, 464-481. [CrossRef]

8. Kieliszek, M.; Piwowarek, K.; Kot, A.M.; Błażejak, S.; Chlebowska-Śmigiel, A.; Wolska, I. Pollen and Bee Bread as New HealthOriented Products: A Review. Trends Food Sci. Technol. 2018, 71, 170-180. [CrossRef]

9. Barene, I.; Daberte, I.; Siksna, S. Investigation of Bee Bread and Development of Its Dosage Forms. Med. Teor. Prakt. 2014, 21, 16-22. [CrossRef]

10. Andjelkovic, B.; Jevtic, G.; Markovic, J.; Mladenovic, M.; Pseva, V. Quality of Honey Bee Bread Collected in Spring. J. Hyg. Eng. Des. 2012, 1, 275-277.

11. Mohammad, S.M.; Mahmud-Ab-Rashid, N.-K.; Zawawi, N. Botanical Origin and Nutritional Values of Bee Bread of Stingless Bee (Heterotrigona itama) from Malaysia. J. Food Qual. 2020, 2020, 2845757. [CrossRef]

12. Othman, Z.A.; Noordin, L.; Wan Ghazali, W.S.; Omar, N.; Mohamed, M. Nutritional, Phytochemical and Antioxidant Analysis of Bee Bread from Different Regions of Malaysia. Indian J. Pharm. Sci. 2019, 81, 955-960. [CrossRef]

13. Donkersley, P.; Rhodes, G.; Pickup, R.W.; Jones, K.C.; Power, E.F.; Wright, G.A.; Wilson, K. Nutritional Composition of Honey Bee Food Stores Vary with Floral Composition. Oecologia 2017, 185, 749-761. [CrossRef] [PubMed]

14. DeGrandi-Hoffman, G.; Eckholm, B.J.; Huang, M.H. A Comparison of Bee Bread Made by Africanized and European Honey Bees (Apis mellifera) and Its Effects on Hemolymph Protein Titers. Apidologie 2013, 44, 52-63. [CrossRef]

15. Bayram, N.E.; Gercek, Y.C.; Çelik, S.; Mayda, N.; Kostić, A.Ž.; Dramićanin, A.M.; Özkök, A. Phenolic and Free Amino Acid Profiles of Bee Bread and Bee Pollen with the Same Botanical Origin-Similarities and Differences. Arab. J. Chem. 2021, $14,103004$. [CrossRef]

16. Pirini, A.; Conte, L.S.; Francioso, O.; Lercker, G. Capillary Gas Chromatographic Determination of Free Amino Acids in Honey as a Means of Discrimination between Different Botanical Sources. J. High Resolut. Chromatogr. 1992, 15, 165-170. [CrossRef]

17. Elnesr, S.; Elwan, H.; Xu, Q.; Xie, C.; Dong, X.; Zou, X. Effects of in Ovo Injection of Sulfur-Containing Amino Acids on Heat Shock Protein 70, Corticosterone Hormone, Antioxidant Indices, and Lipid Profile of Newly Hatched Broiler Chicks Exposed to Heat Stress during Incubation. Poult. Sci. 2019, 98, 2290-2298. [CrossRef] [PubMed]

18. Birmani, M.W.; Raza, A.; Nawab, A.; Tang, S.; Ghani, M.W.; Li, G.; Xiao, M.; An, L. Importance of Arginine as Immune Regulator in Animal Nutrition. Int. J. Vet. Sci. Res. 2019, 5, 1-10. [CrossRef]

19. Haydak, M.H. Honey Bee Nutrition. Annu. Rev. Entomol. 1970, 15, 143-156. [CrossRef]

20. Bakour, M.; Fernandes, Â.; Barros, L.; Sokovic, M.; Ferreira, I.C.F.R. Badiaa lyoussi Bee Bread as a Functional Product: Chemical Composition and Bioactive Properties. LWT Food Sci. Technol. 2019, 109, 276-282. [CrossRef]

21. Dranca, F.; Ursachi, F.; Oroian, M. Bee Bread: Physicochemical Characterization and Phenolic Content Extraction Optimization. Foods 2020, 9, 1358. [CrossRef]

22. Urcan, A.; Criste, A.; Dezmirean, D.; Mărgăoan, R.; Caeiro, A.; Graça Campos, M. Similarity of Data from Bee Bread with the Same Taxa Collected in India and Romania. Molecules 2018, 23, 2491. [CrossRef]

23. Da Silva, G.R.; da Natividade, T.B.; Camara, C.A.; da Silva, E.M.S.; dos Santos, F.d.A.R.; Silva, T.M.S. Identification of Sugar Amino Acids and Minerals from the Pollen of Jandaíra Stingless Bees (Melipona subnitida). Food Nutr. Sci. 2014, $2014,46901$.

24. Kaplan, M.; Karaoğlu, Ö.; Silici, S. An Evaluation on Bee Bread: Chemical and Palynological Analysis. Mellifera 2019, 19, 21-29.

25. Kaplan, M.; Karaoglu, Ö.; Eroglu, N. Sibel Silici Fatty Acids and Proximate Composition of Beebread. Food Technol. Biotechnol. 2016, 54, 497-504. [CrossRef] [PubMed] 
26. Thakur, M.; Nanda, V. Exploring the Physical, Functional, Thermal, and Textural Properties of Bee Pollen from Different Botanical Origins of India. J. Food Process Eng. 2020, 43, e12935. [CrossRef]

27. Yang, K.; Wu, D.; Ye, X.; Liu, D.; Chen, J.; Sun, P. Characterization of Chemical Composition of Bee Pollen in China. J. Agric. Food Chem. 2013, 61, 708-718. [CrossRef]

28. AL-Kahtani, S.N. Fatty Acids and B Vitamins Contents in Honey Bee Collected Pollen in Relation to Botanical Origin. Sci. J. King Faisal Univ. 2017, 18, 41-48.

29. Dong, J.; Yang, Y.; Wang, X.; Zhang, H. Fatty Acid Profiles of 20 Species of Monofloral Bee Pollen from China. J. Apic. Res. 2015, 54, 503-511. [CrossRef]

30. Eleazu, C.; Suleiman, J.B.; Othman, Z.A.; Zakaria, Z.; Nna, V.U.; Hussain, N.H.N.; Mohamed, M. Bee Bread Attenuates High Fat Diet Induced Renal Pathology in Obese Rats via Modulation of Oxidative Stress, Downregulation of NF-KB Mediated Inflammation and Bax Signalling. Arch. Physiol. Biochem. 2020, 1-17. [CrossRef] [PubMed]

31. Ciric, J.; Spiric, D.; Baltic, T.; Janjic, J.; Petronijevic, R.; Simunovic, S.; Djordjevic, V. Element Concentration and Fatty Acid Composition of Serbian Bee Bread; IOP Publishing: Bristol, UK, 2019; Volume 333, p. 012050.

32. Greer, R.C.; Marklund, M.; Anderson, C.A.; Cobb, L.K.; Dalcin, A.T.; Henry, M.; Appel, L.J. Potassium-Enriched Salt Substitutes as a Means to Lower Blood Pressure: Benefits and Risks. Hypertension 2020, 75, 266-274. [CrossRef] [PubMed]

33. Gonzalez, A.A.; Gallardo, M.; Cespedes, C.; Vio, C.P. Potassium Intake Prevents the Induction of the Renin-Angiotensin System and Increases Medullary ACE2 and COX-2 in the Kidneys of Angiotensin II-Dependent Hypertensive Rats. Front. Pharmacol. 2019, 10, 1212. [CrossRef]

34. Ji, F.; Zhang, S.; An, Y.; Wang, Z.; Shao, Y.; Du, S.; Li, X.; Sun, X. Influence of Dietary Phosphorus Concentrations on the Performance of Rearing Pigeons (Columba Livia), and Bone Properties of Squabs. Poult. Sci. 2022, 101744. [CrossRef]

35. Anwar, H.; Hussain, G.; Mustafa, I. Antioxidants from Natural Sources. Antioxid. Foods Appl. 2018, 1-27.

36. Kalaycığlu, Z.; Kaygusuz, H.; Döker, S.; Kolaylı, S.; Erim, F.B. Characterization of Turkish Honeybee Pollens by Principal Component Analysis Based on Their Individual Organic Acids, Sugars, Minerals, and Antioxidant Activities. LWT 2017, 84, 402-408. [CrossRef]

37. Wu, S.; Xu, C.; Zhu, Y.; Zheng, L.; Zhang, L.; Hu, Y.; Yu, B.; Wang, Y.; Xu, F. Biofilm-Sensitive Photodynamic Nanoparticles for Enhanced Penetration and Antibacterial Efficiency. Adv. Funct. Mater. 2021, 31, 2103591. [CrossRef]

38. Peláez, A.L.; Cataño, C.S.; Yepes, E.Q.; Villarroel, R.G.; de Antoni, G.; Giannuzzi, L. Inhibitory Activity of Lactic and Acetic Acid on Aspergillus Flavus Growth for Food Preservation. Food Control 2012, 24, 177-183. [CrossRef]

39. Ares, A.M.; Valverde, S.; Bernal, J.L.; Nozal, M.J.; Bernal, J. Extraction and Determination of Bioactive Compounds from Bee Pollen. J. Pharm. Biomed. Anal. 2018, 147, 110-124. [CrossRef] [PubMed]

40. Loper, G.M.; Standifer, L.N.; Thompson, M.J.; Gilliam, M. Biochemistry and Microbiology of Bee-Collected Almond (Prunus dulcis) Pollen and Bee Bread. I-Fatty Acids, Sterols, Vitamins and Minerals. Apidologie 1980, 11, 63-73. [CrossRef]

41. Thakur, M.; Nanda, V. Composition and Functionality of Bee Pollen: A Review. Trends Food Sci. Technol. 2020, 98, 82-106. [CrossRef]

42. Laaroussi, H.; Ferreira-Santos, P.; Genisheva, Z.; Bakour, M.; Ousaaid, D.; Teixeira, J.A.; Lyoussi, B. Unraveling the Chemical Composition, Antioxidant, $\alpha$-Amylase and $\alpha$-Glucosidase Inhibition of Moroccan Propolis. Food Biosci. 2021, 42, 101160. [CrossRef]

43. Hudz, N.; Ivanova, R.; Brindza, J.; Grygorieva, O.; Schubertová, Z.; Ivanišová, E. Approaches to the Determination of Antioxidant Activity of Extracts from Bee Bread and Safflower Leaves and Flowers. Potravinarstvo 2017, 11, 480-488. [CrossRef]

44. Oltica, S.; Mărghitaş, L.A.; Dezmirean, D. Examination of antioxidant capacity of beebread extracts by different complementary assays. In Bulletin of the University of Agricultural Sciences \& Veterinary Medicine Cluj-Napoca; Animal Science \& Biotechnologies; Academic Press: Cambridge, MA, USA, 2007; Volume 63, p. 64.

45. Silva, B.N.; Cadavez, V.; Ferreira-Santos, P.; Alves, M.J.; Ferreira, I.C.; Barros, L.; Teixeira, J.A.; Gonzales-Barron, U. Chemical Profile and Bioactivities of Extracts from Edible Plants Readily Available in Portugal. Foods 2021, 10, 673. [CrossRef] [PubMed]

46. Sobral, F.; Calhelha, R.; Barros, L.; Dueñas, M.; Tomás, A.; Santos-Buelga, C.; Vilas-Boas, M.; Ferreira, I. Flavonoid Composition and Antitumor Activity of Bee Bread Collected in Northeast Portugal. Molecules 2017, 22, 248. [CrossRef] [PubMed]

47. Aylanc, V.; Tomás, A.; Russo-Almeida, P.; Falcão, S.I.; Vilas-Boas, M. Assessment of Bioactive Compounds under Simulated Gastrointestinal Digestion of Bee Pollen and Bee Bread: Bioaccessibility and Antioxidant Activity. Antioxidants 2021, $10,651$. [CrossRef]

48. Baltrušaitytè, V.; Venskutonis, P.R.; Čeksterytė, V. Radical Scavenging Activity of Different Floral Origin Honey and Beebread Phenolic Extracts. Food Chem. 2007, 101, 502-514. [CrossRef]

49. Tavdidishvili, D.; Khutsidze, T.; Pkhakadze, M.; Vanidze, M.; Kalandia, A. Flavonoids in Georgian Bee Bread and Bee Pollen. J. Chem. Chem. Eng. 2014, 8, 676-681.

50. Markiewicz-Żukowska, R.; Naliwajko, S.K.; Bartosiuk, E.; Moskwa, J.; Isidorov, V.; Soroczyńska, J.; Borawska, M.H. Chemical Composition and Antioxidant Activity of Beebread, and Its Influence on the Glioblastoma Cell Line (U87MG). J. Apic. Sci. 2013, 57, 147-157. [CrossRef]

51. Bakour, M.; Hammas, N.; Laaroussi, H.; Ousaaid, D.; Fatemi, H.E.; Aboulghazi, A.; Soulo, N.; Lyoussi, B. Moroccan Bee Bread Improves Biochemical and Histological Changes of the Brain, Liver, and Kidneys Induced by Titanium Dioxide Nanoparticles. BioMed Res. Int. 2021, 2021, 6632128. [CrossRef] 
52. Elsayed, N.; El-Din, H.S.; Altemimi, A.B.; Ahmed, H.Y.; Pratap-Singh, A.; Abedelmaksoud, T.G. In Vitro Antimicrobial, Antioxidant and Anticancer Activities of Egyptian Citrus Beebread. Molecules 2021, 26, 2433. [CrossRef]

53. Hsu, C.-K.; Wang, D.-Y.; Wu, M.-C. A Potential Fungal Probiotic Aureobasidium Melanogenum CK-CsC for the Western Honey Bee, Apis mellifera. J. Fungi 2021, 7, 508. [CrossRef]

54. Dimov, S.G.; Zagorchev, L.; Iliev, M.; Dekova, T.; Ilieva, R.; Kitanova, M.; Georgieva-Miteva, D.; Dimitrov, M.; Peykov, S. A Snapshot Picture of the Fungal Composition of Bee Bread in Four Locations in Bulgaria, Differing in Anthropogenic Influence. J. Fungi 2021, 7, 845. [CrossRef] [PubMed]

55. Iorizzo, M.; Pannella, G.; Lombardi, S.J.; Ganassi, S.; Testa, B.; Succi, M.; Sorrentino, E.; Petrarca, S.; de Cristofaro, A.; Coppola, R. Inter-and Intra-Species Diversity of Lactic Acid Bacteria in Apis mellifera Ligustica Colonies. Microorganisms 2020, 8 , 1578. [CrossRef] [PubMed]

56. Mohammad, S.M.; Mahmud-Ab-Rashid, N.-K.; Zawawi, N. Probiotic Properties of Bacteria Isolated from Bee Bread of Stingless Bee Heterotrigona itama. J. Apic. Res. 2020, 60, 172-187. [CrossRef]

57. Machado De-Melo, A.A.; de Almeida-Muradian, L.B.; Sancho, M.T.; Pascual-Maté, A. Composition and Properties of Apis mellifera Honey: A Review. J. Apic. Res. 2018, 57, 5-37. [CrossRef]

58. Gilliam, M.; Prest, D.B.; Lorenz, B.J. Microbiology of Pollen and Bee Bread: Taxonomy and Enzymology of Molds. Apidologie 1989, 20, 53-68. [CrossRef]

59. Salazar-González, C.; Díaz-Moreno, C. The Nutritional and Bioactive Aptitude of Bee Pollen for a Solid-State Fermentation Process. J. Apic. Res. 2016, 55, 161-175. [CrossRef]

60. Ispirli, H.; Dertli, E. Detection of Fructophilic Lactic Acid Bacteria (FLAB) in Bee Bread and Bee Pollen Samples and Determination of Their Functional Roles. J. Food Process. Preserv. 2021, 45, e15414. [CrossRef]

61. Akhir, R.A.M.; Bakar, M.F.A.; Sanusi, S.B. Antioxidant and Antimicrobial Activity of Stingless Bee Bread and Propolis Extracts; AIP Publishing LLC: Melville, NY, USA, 2017; Volume 1891, p. 020090.

62. Zuluaga, C.M.; Serratob, J.C.; Quicazana, M.C. Chemical, Nutritional and Bioactive Characterization of Colombian Bee-Bread Chem. Eng. 2015, 43, 175-180.

63. Bakour, M.; Al-Waili, N.S.; El Menyiy, N.; Imtara, H.; Figuira, A.C.; Al-Waili, T.; Lyoussi, B. Antioxidant Activity and Protective Effect of Bee Bread (Honey and Pollen) in Aluminum-Induced Anemia, Elevation of Inflammatory Makers and Hepato-Renal Toxicity. J. Food Sci. Technol. 2017, 54, 4205-4212. [CrossRef]

64. Bakour, M.; Menyiy, N.E.; Ghouizi, A.E.; Lyoussi, B. Hypoglycemic, Hypolipidemic and Hepato-Protective Effect of Bee Bread in Streptozotocin-Induced Diabetic Rats. Avicenna J. Phytomed. 2021, 11, 10.

65. Baltrušaitytè, V.; Venskutonis, P.R.; Čeksterylè, V. Antibacterial Activity of Honey and Beebread of Different Origin Against S. Aureus and S. Epidermidis. Food Technol. Biotechnol. 2007, 45, 201-208.

66. Ivanišová, E.; Kačániová, M.; Frančáková, H.; Petrová, J.; Hutková, J.; Brovarskyi, V.; Velychko, S.; Adamchuk, L.; Schubertová, Z.; Musilová, J. Bee Bread-Perspective Source of Bioactive Compounds for Future. Potravinarstvo 2015, 9, 592-598. [CrossRef]

67. Keskin, M.; Özkök, A. $\alpha$-Amylase Inhibition Properties of Bee Pollen and Bee Bread (Perga). Hacet. J. Biol. Chem. 2020, 48, 389-393. [CrossRef]

68. Nagai, T.; Nagashima, T.; Myoda, T.; Inoue, R. Preparation and Functional Properties of Extracts from Bee Bread. Food Nahr. 2004, 48, 226-229. [CrossRef] [PubMed]

69. Nagai, T.; Nagashima, T.; Suzuki, N.; Inoue, R. Antioxidant Activity and Angiotensin I-Converting Enzyme Inhibition by Enzymatic Hydrolysates from Bee Bread. Z. Naturforsch. C 2005, 60, 133-138. [CrossRef]

70. Fallah, M.; Najafi, F.; Kavoosi, G. Bee Propolis, Bee Bread, and Royal Jelly: Proximate Analysis, Fatty Acid Composition, Nutritional Quality, and Anti-Amylase Activity; Research Gate: Berlin, Germany, 2021.

71. Jo, Y.H.; Lee, S.; Yeon, S.W.; Ryu, S.H.; Turk, A.; Hwang, B.Y.; Han, Y.K.; Lee, K.Y.; Lee, M.K. Anti- $\alpha$-Glucosidase and AntiOxidative Isoflavonoids from the Immature Fruits of Maclura Tricuspidata. Phytochemistry 2022, 194, 113016. [CrossRef]

72. Węglińska, M.; Szostak, R.; Kita, A.; Nemś, A.; Mazurek, S. Determination of Nutritional Parameters of Bee Pollen by Raman and Infrared Spectroscopy. Talanta 2020, 212, 120790. [CrossRef]

73. Bartkiene, E.; Lele, V.; Sakiene, V.; Zavistanaviciute, P.; Zokaityte, E.; Dauksiene, A.; Jagminas, P.; Klupsaite, D.; Bliznikas, S.; Ruzauskas, M. Variations of the Antimicrobial, Antioxidant, Sensory Attributes and Biogenic Amines Content in LithuaniaDerived Bee Products. LWT 2020, 118, 108793. [CrossRef]

74. Hotel, A.C.P.; Cordoba, A. Health and Nutritional Properties of Probiotics in Food Including Powder Milk with Live Lactic Acid Bacteria. Prevention 2001, 5, 1-10.

75. Isolauri, E.; Salminen, S.; Ouwehand, A.C. Probiotics. Best Pract. Res. Clin. Gastroenterol. 2004, 18, 299-313. [CrossRef] [PubMed]

76. Cerdó, T.; Ruíz, A.; Suárez, A.; Campoy, C. Probiotic, Prebiotic, and Brain Development. Nutrients 2017, 9, 1247. [CrossRef] [PubMed]

77. Markowiak, P.; Śliżewska, K. Effects of Probiotics, Prebiotics, and Synbiotics on Human Health. Nutrients 2017, 9, 1021. [CrossRef] [PubMed]

78. Ceccarelli, G.; Scagnolari, C.; Pugliese, F.; Mastroianni, C.M.; d'Ettorre, G. Probiotics and COVID-19. Lancet Gastroenterol. Hepatol. 2020, 5, 721-722. [CrossRef] 
79. Terpou, A.; Papadaki, A.; Lappa, I.K.; Kachrimanidou, V.; Bosnea, L.A.; Kopsahelis, N. Probiotics in Food Systems: Significance and Emerging Strategies towards Improved Viability and Delivery of Enhanced Beneficial Value. Nutrients 2019, $11,1591$. [CrossRef]

80. Mărgăoan, R.; Cornea-Cipcigan, M.; Topal, E.; Kösoğlu, M. Impact of Fermentation Processes on the Bioactive Profile and Health-Promoting Properties of Bee Bread, Mead and Honey Vinegar. Processes 2020, 8, 1081. [CrossRef]

81. Toutiaee, S.; Mojgani, N.; Harzandi, N.; Moharrami, M.; Mokhberosafa, L. In-vitro Probiotic and Safety Attributes of Bacillus Spp. Isolated from Beebread, Honey Samples and Digestive Tract of Honeybees Apis mellifera. Lett. Appl. Microbiol. 2022. ahead of print. [CrossRef]

82. Khalifa, S.A.; Elashal, M.; Kieliszek, M.; Ghazala, N.E.; Farag, M.A.; Saeed, A.; Xiao, J.; Zou, X.; Khatib, A.; Göransson, U. Recent Insights into Chemical and Pharmacological Studies of Bee Bread. Trends Food Sci. Technol. 2020, 97, 300-316. [CrossRef]

83. Abouda, I.Z.; Zerdani, I.; Kalalou, M.; Faid, M.T. Ahami The Antibacterial Activity of Moroccan Bee Bread and Bee-Pollen (Fresh and Dried) against Pathogenic Bacteria. Res. J. Microbiol. 2011, 6, 376-384.

84. Didaras, N.A.; Kafantaris, I.; Dimitriou, T.G.; Mitsagga, C.; Karatasou, K.; Giavasis, I.; Stagos, D.; Amoutzias, G.D.; Hatjina, F.; Mossialos, D. Biological Properties of Bee Bread Collected from Apiaries Located across Greece. Antibiotics 2021, $10,555$. [CrossRef]

85. Pełka, K.; Otłowska, O.; Worobo, R.W.; Szweda, P. Bee Bread Exhibits Higher Antimicrobial Potential Compared to Bee Pollen. Antibiotics 2021, 10, 125. [CrossRef] [PubMed]

86. Ahmad, F.; Lani, M.; Nazari, S.; Hajar, N.; Hassan, K.; Razak, S.; Hassan, Z. Antioxidant and Antimicrobial Properties of Honey, Propolis and Bee Bread of Stingless Bee (Geniotrigona thoracica). Asian J. Agric. Biol. 2019, 1, 1-10.

87. Suleiman, J.B.; Mohamed, M.; Abu Bakar, A.B.; Nna, V.U.; Zakaria, Z.; Othman, Z.A.; Aroyehun, A.B. Chemical Profile, Antioxidant Properties and Antimicrobial Activities of Malaysian Heterotrigona itama Bee Bread. Molecules 2021, $26,4943$. [CrossRef]

88. Hudz, N.; Yezerska, O.; Grygorieva, O.; Brindza, J.; Felsöciová, S.; Kačániová, M.; Wieczorek, P.P. Analytical Procedure Elaboration of Total Flavonoid Content Determination and Antimicrobial Activity of Bee Bread Extracts. Acta Pol. Pharm.-Drug Res. 2019, 76, 439-452. [CrossRef]

89. Bakour, M.; Laaroussi, H.; Ousaaid, D.; Oumokhtar, B.; Lyoussi, B. Antioxidant and Antibacterial Effects of Pollen Extracts on Human Multidrug-Resistant Pathogenic Bacteria. J. Food Qual. 2021, 2021, 5560182. [CrossRef]

90. Didaras, N.A.; Dimitriou, T.; Daskou, M.; Karatasou, K.; Mossialos, D. In vitro assessment of the antiviral activity of Greek bee bread and bee collected pollen against enterovirus D68. J. Microbiol. Biotechnol. Food Sci. 2021, 20, e4859.

91. Al-Hatamleh, M.A.I.; Hatmal, M.M.; Sattar, K.; Ahmad, S.; Mustafa, M.Z.; Bittencourt, M.D.C.; Mohamud, R. Antiviral and Immunomodulatory Effects of Phytochemicals from Honey against COVID-19: Potential Mechanisms of Action and Future Directions. Molecules 2020, 25, 5017. [CrossRef]

92. Lima, W.G.; Brito, J.C.M.; da Cruz Nizer, W.S. Bee Products as a Source of Promising Therapeutic and Chemoprophylaxis Strategies against COVID-19 (SARS-CoV-2). Phytother. Res. 2020, 35, 743-750. [CrossRef] [PubMed]

93. Jain, A.S.; Sushma, P.; Dharmashekar, C.; Beelagi, M.S.; Prasad, S.K.; Shivamallu, C.; Prasad, A.; Syed, A.; Marraiki, N.; Prasad, K.S In Silico Evaluation of Flavonoids as Effective Antiviral Agents on the Spike Glycoprotein of SARS-CoV-2. Saudi J. Biol. Sci. 2021, 28, 1040-1051. [CrossRef] [PubMed]

94. Hashem, H. In Silico Approach of Some Selected Honey Constituents as SARS-CoV-2 Main Protease (COVID-19) Inhibitors. Eur. J. Med. Oncol. 2020, 4, 196-200. [CrossRef]

95. Bouarab Chibane, L.; Degraeve, P.; Ferhout, H.; Bouajila, J.; Oulahal, N. Plant Antimicrobial Polyphenols as Potential Natural Food Preservatives. J. Sci. Food Agric. 2019, 99, 1457-1474. [CrossRef] [PubMed]

96. Ultee, A.; Bennik, M.; Moezelaar, R. The Phenolic Hydroxyl Group of Carvacrol Is Essential for Action against the Food-Borne Pathogen Bacillus Cereus. Appl. Environ. Microbiol. 2002, 68, 1561-1568. [CrossRef] [PubMed]

97. Wang, S.; Yao, J.; Zhou, B.; Yang, J.; Chaudry, M.T.; Wang, M.; Xiao, F.; Li, Y.; Yin, W. Bacteriostatic Effect of Quercetin as an Antibiotic Alternative in Vivo and Its Antibacterial Mechanism in Vitro. J. Food Prot. 2018, 81, 68-78. [CrossRef]

98. Yu, L.; Shang, F.; Chen, X.; Ni, J.; Yu, L.; Zhang, M.; Sun, D.; Xue, T. The Anti-Biofilm Effect of Silver-Nanoparticle-Decorated Quercetin Nanoparticles on a Multi-Drug Resistant Escherichia Coli Strain Isolated from a Dairy Cow with Mastitis. PeerJ 2018, 6, e5711. [CrossRef]

99. Huang, Y.-H.; Huang, C.-C.; Chen, C.-C.; Yang, K.-J.; Huang, C.-Y. Inhibition of Staphylococcus aureus PriA Helicase by Flavonol Kaempferol. Protein J. 2015, 34, 169-172. [CrossRef]

100. Yu, Y.; Yi, Z.; Liang, Y.-Z. Validate Antibacterial Mode and Find Main Bioactive Components of Traditional Chinese Medicine Aquilegia Oxysepala. Bioorganic Med. Chem. Lett. 2007, 17, 1855-1859. [CrossRef] [PubMed]

101. Pham, V.H.; Abbas, W.; Huang, J.; He, Q.; Zhen, W.; Guo, Y.; Wang, Z. Effect of Blending Encapsulated Essential Oils and Organic Acids as an Antibiotic Growth Promoter Alternative on Growth Performance and Intestinal Health in Broilers with Necrotic Enteritis. Poult. Sci. 2022, 101, 101563. [CrossRef] [PubMed]

102. Brul, S.; Coote, P. Preservative Agents in Foods: Mode of Action and Microbial Resistance Mechanisms. Int. J. Food Microbiol. 1999, 50, 1-17. [CrossRef]

103. Masoura, M.; Passaretti, P.; Overton, T.W.; Lund, P.A.; Gkatzionis, K. Use of a Model to Understand the Synergies Underlying the Antibacterial Mechanism of H 2 O 2-Producing Honeys. Sci. Rep. 2020, 10, 1-14. [CrossRef] [PubMed] 
104. Yagnik, D.; Ward, M.; Shah, A.J. Antibacterial Apple Cider Vinegar Eradicates Methicillin Resistant Staphylococcus aureus and Resistant Escherichia Coli. Sci. Rep. 2021, 11, 1-7. [CrossRef]

105. Pothimon, R.; Krusong, W.; Daetae, P.; Tantratian, S.; Gullo, M. Determination of Antifungal Volatile Organic Compounds of Upland Rice Vinegar and Their Inhibition Effects on Aspergillus Flavus in Dried Chili Pepper. Food Biosci. 2022, $46,101543$. [CrossRef]

106. Othman, Z.A.; Zakaria, Z.; Suleiman, J.B.; Nna, V.U.; Che Romli, A.; Wan Ghazali, W.S.; Mohamed, M. Bee Bread Ameliorates Vascular Inflammation and Impaired Vasorelaxation in Obesity-Induced Vascular Damage Rat Model: The Role of ENOS/NO/CGMP-Signaling Pathway. Int. J. Mol. Sci. 2021, 22, 4225. [CrossRef]

107. Suleiman, J.B.; Nna, V.U.; Zakaria, Z.; Othman, Z.A.; Eleazu, C.O.; Abu Bakar, A.B.; Ahmad, A.; Usman, U.Z.; Abdul Rahman, W.F.W.; Mohamed, M. Protective Effects of Bee Bread on Testicular Oxidative Stress, NF-KB-Mediated Inflammation, Apoptosis and Lactate Transport Decline in Obese Male Rats. Biomed. Pharmacother. 2020, 131, 110781. [CrossRef] [PubMed]

108. Othman, Z.A.; Wan Ghazali, W.S.; Noordin, L.; Mohd Yusof, N.A.; Mohamed, M. Phenolic Compounds and the Anti-Atherogenic Effect of Bee Bread in High-Fat Diet-Induced Obese Rats. Antioxidants 2019, 9, 33. [CrossRef]

109. Martiniakova, M.; Blahova, J.; Kovacova, V.; Babikova, M.; Mondockova, V.; Kalafova, A.; Capcarova, M.; Omelka, R. Bee Bread Can Alleviate Lipid Abnormalities and Impaired Bone Morphology in Obese Zucker Diabetic Rats. Molecules 2021, $26,2616$. [CrossRef]

110. Haščík, P. Chemical composition of muscle after bee bread application in the nutrition of Japanese quails. J. Microbiol. Biotechnol. Food Sci. 2020, 9, 831-835. [CrossRef]

111. Li, Z.; Huang, Q.; Liu, Y.; Peng, C.; Zeng, Z. Natural Bee Bread Positively Regulates Lipid Metabolism in Rats. Int. J. Agric. Sci. Food Technol. 2021, 7, 266-271.

112. Doğanyiğit, Z.; YAKAN, B.; Soylu, M.; Kaymak, E.; Silici, S. The Effects of Feeding Obese Rats with Bee Bread on Leptin and Ghrelin Expression. Turk. J. Zool. 2020, 44, 114-125. [CrossRef]

113. Martiniakova, M.; Blahova, J.; Kovacova, V.; Mondockova, V.; Babosova, R.; Kalafova, A.; Capcarova, M.; Omelka, R. Effects of Bee Bread, Cornelian Cherries Treatment on the Femoral Bone Structure Using Zucker Diabetic Fatty Rats as an Animal Model. Veter. Med. 2021, 66, 342-349. [CrossRef]

114. Čeksterytė, V.; Balžekas, J.; Baltuškevičius, A.; Jurgevičius, E. The Use of Beebread-Honey Mixture in the Treatment of Liver Diseases in Alcohol-Dependent Patients. Chem. Technol. 2012, 60, 62-66. [CrossRef]

115. Kas'ianenko, V.I.; Komisarenko, I.A.; Dubtsova, E.A. Correction of atherogenic dyslipidemia with honey, pollen and bee bread in patients with different body mass. Ter. Arkh. 2011, 83, 58-62. [PubMed]

116. Jarušaitienè, D.; Jankauskienè, J.; Čeksterytè, V. Changes of Ocular Signs in Children with Thyroid Diseases after Intake of Bee Bread. Chem. Technol. 2012, 61, 7-10. [CrossRef]

117. Chen, C.K.; Ping, F.W.C.; Ooi, F.K.; Mohamed, M. Effects of Bee Bread Supplementation during Recovery on Time Trial Performance and Selected Physiological Parameters. Int. J. Pharma Bio Sci. 2018, 9, 281-288. [CrossRef]

118. Fadzel, W.C.P.; Chen, C.K.; Ooi, F.K.; Mohamed, M. Effects of Bee Bread Supplementation on Endurance Running Performance and Total Antioxidant Status in Recreational Athletes. Int. J. Appl. Res. Nat. Prod. 2018, 11, 17-23.

119. Semkiw, P.; Skubida, P. Bee Bread Production-A New Source of Income for Beekeeping Farms? Agriculture 2021, 11, 468. [CrossRef]

120. Bakour, M.; Laaroussi, H.; El Menyiy, N.; Elaraj, T.; El Ghouizi, A.; Lyoussi, B. The Beekeeping State and Inventory of MelliferoMedicinal Plants in the North-Central of Morocco. Sci. World J. 2021, 2021, 1-12. [CrossRef] [PubMed]

121. Gupta, R.K.; Reybroeck, W.; van Veen, J.W.; Gupta, A. Beekeeping for Poverty Alleviation and Livelihood Security; Springer: Berlin/Heidelberg, Germany, 2014.

122. AbdulRahaman, A.A.; Liadi, M.; Musa, A.; Kolawole, O.; Oladele, F. Pollens in Bee-Breads as an Indicator of Honey Sources. Bangladesh J. Sci. Ind. Res. 2013, 48, 247-252. [CrossRef]

123. Chica, M. Authentication of Bee Pollen Grains in Bright-field Microscopy by Combining One-class Classification Techniques and Image Processing. Microsc. Res. Tech. 2012, 75, 1475-1485. [CrossRef]

124. Wang, Z.; Ren, P.; Wu, Y.; He, Q. Recent Advances in Analytical Techniques for the Detection of Adulteration and Authenticity of Bee Products-A Review. Food Addit. Contam. Part A 2021, 38, 533-549. [CrossRef]

125. Araújo, J.S.; Chambó, E.D.; de Costa, M.A.P.C.; Cavalcante da Silva, S.M.P.; Lopes de Carvalho, C.A.; Estevinho, L.M. Chemical Composition and Biological Activities of Mono- and Heterofloral Bee Pollen of Different Geographical Origins. Int. J. Mol. Sci. 2017, 18, 921. [CrossRef]

126. Kafantaris, I.; Amoutzias, G.D.; Mossialos, D. Foodomics in Bee Product Research: A Systematic Literature Review. Eur. Food Res. Technol. 2021, 247, 309-331. [CrossRef] 